\title{
AZ ELKÖTELEZETTEK, A CSALÓDOTTAK, A TAPASZTALATSZERZŐK ÉS AKIK MEGPRÓBÁLTÁK - AZ ORVOS- ÉS EGÉSZSÉGTUDOMÁNYI HALLGATÓK COVID-19 JÁRVÁNY ALATTI ÖNKÉNTESSÉGÉNEK VIZSGÁLATA ${ }^{1}$
}

\author{
BARTAL ANNA MÁRIA² - FÉNYES HAJNALKA ${ }^{3}$ - SZALÓCZY NÓRA4
}

DOI: https://doi.org/10.53585/OnkSzem.2021.2.5-35

\section{Absztrakt}

Tanulmányunk egy különleges helyzetben, a COVID-19 járvány három hulláma alatt vizsgálta 395 orvosés egészségtudományi szakos hallgató önkéntességét. Mivel Magyarországon a hallgatók pandémia alatti önkéntessége különböző anyagi juttatásokkal ösztönzött volt, ezért vizsgáltuk az önkénteselköteleződés és az anyagi ösztönzők kapcsolatát. Eredményeink szerint a válaszadók csak kétötödére volt jellemző az a fajta „érdeknélküli” önkéntes-elköteleződés, amit nem befolyásoltak az anyagi juttatások. Vizsgáltuk azt is, hogy a korábbi önkéntes tapasztalataik, illetve a pandémia alatti önkéntességük gyakorisága miként befolyásolta önkéntes-motivációikat. Négy alcsoportot tudtuk megkülönböztetni, úgy mint: az „elkötelezetteket” - akik tapasztalt és több időszakban is önkéntesek voltak -, erős altruista motivációk és önkéntes-elköteleződés jellemezte. A „csalódottak” - akik a minta legkisebb hányadát alkották - szintén tapasztalt önkéntesek voltak, de vélhetően a járványhelyzetben szerzett negatív élményeik miatt gyenge motivációs-bázist mutattak. A válaszadók közel kétharmada a járványhelyzetben próbálta ki magát először az önkéntességben. Egyik részük a „tapasztalatszerzők” több időszakban voltak önkéntesek, individualista motivációkkal és alacsonyabb elköteleződéssel, addig a másik részük egyszer próbálta ki az önkéntességet és leginkább a szakmai környezet visszajelzésétől függő, önmegerősítés vágya motiválta őket.

Eredményeink alapján úgy látjuk, hogy az önkéntesség számos olyan pozitív tapasztalatot és megerősitést is jelentett a COVID-19 járvány önkénteseinek számára, amelyek erősithetik a szakmai elhivatottságukat, ugyanakkor a problémás beteg- és munkatársi kapcsolatok, a külső és belső stressz, trauma kezelésére a hallgatók nem voltak kellően felkészítve.

Kulcsszavak: COVID-19 járvány, önkéntes-elköteleződés, ösztönzők, önkéntes-motivációk, orvos- és egészségtudományi szakos hallgatók,

\footnotetext{
${ }^{1} \mathrm{~A}$ tanulmány az Önkéntes Szemle és a Társadalomtudományi Kutatóközpont szervezésében megvalósult „Az orvos, fogorvos, gyógyszerész és egészségtudományi szakos hallgatók önkéntessége és kirendelése." címú kutatás alapján készült. Jelen tanulmányban csak az orvos, fogorvos, gyógyszerész és egészségtudományi szakos hallgatók önkéntességével foglalkozunk. A szerzők köszönetet mondanak Dorner Lászlónak, Kmetty Zoltánnak, Lukács Ágnesnek és Sebestény Istvánnak a tanulmányhoz füzött hasznos megjegyzéseikért.

${ }^{2}$ Bartal Anna Mária (PhD) szociálpolitikus-szociológus, az Önkéntes Szemle föszerkesztője

3 Fényes Hajnalka (PhD) közgazdász-szociológus, egyetemi docens, Debreceni Egyetem Szociológia és Szociálpolitika Tanszék

${ }^{4}$ Szalóczy Nóra, egészségszociológus, PhD hallgató, tanársegéd, Semmelweis Egyetem Egészségtudományi Kar
} 
The committed, the disappointed, those who gained experienced and those who have tried - An analysis of the volunteering of Hungarian medical and health scinece students during the COVID-19 pandemic

Anna Mária Bartal - Hajnalka Fényes - Nóra Szalóczy

\section{Abstract}

This study examines the voluntary commitment of 395 medical and health science students in an extremely unique situation, in the three waves of the COVID-19 pandemic. Since in Hungary students' volunteering has been encouraged by various financial benefits, we focused on the relationship between their commitment to volunteering and the financial incentives. Based on an online survey, our results show that only two fifths of those questioned had volunteer work with no financial interest.

We also looked at how their previous voluntary engagements and the frequency of volunteering during the pandemic had affected their motivations for doing volunteer work. Based on these aspects, we were able to identify four subgroups. The 'committed' - those who had previous volunteer experiences and who had volunteered for several periods of time during the pandemic - were characterised by strong altruistic motivations and voluntary commitment. The 'disappointed', who made up the smallest proportion of the sample, were also experienced volunteers, but showed a weak motivational base due to their negative experiences during the pandemic. Nevertheless, almost two thirds of those surveyed did voluntary work for the first time in their lives in the pandemic situation. Some of them were "experience seekers" who volunteered for several periods of time during the pandemic and were characterised by individualistic motivation and relatively low level of commitment, while the other part did volunteer work only for one period of time and were driven primarily by a desire for self-affirmation that relied on feedback from the professional environment.

Our results suggest that volunteering during the Covid-19 pandemic provided the medical and health science students surveyed with a number of positive experiences and reinforcements that could bolster their future professional engagement. Even though they were not adequately prepared for the problematic relationship between patients and staff as well as the external stresses and trauma.

Keywords: COVID-19 pandemic, commitment to volunteering, incentives, motivations of volunteer, students of medical and health sciences,

\section{BEVEZETÉS}

A COVID-19 vírus 2019. decemberi megjelenése és gyors, járványszerű terjedése világszerte jelentősen túlterhelte az egészségügyi rendszereket. A kormányzatok különböző stratégiákat alkalmaztak azért, hogy a járvány okozta betegellátási feszültségeket oldani tudják: az Egyesült Királyság, Olaszország vagy például a New York-i Egyetem lehetővé tette az utolsó éves orvostanhallgatók számára, hogy korábban diplomázzanak, és mielőbb munkába álljanak (Harvey 2020; DeWitt 2020). Gyakori megoldás volt, hogy nyugdíjas orvosokat, ápolókat hívtak vissza, illetve egészségügyi dolgozókat irányítottak át a COVID-19 osztályokra. Csaknem minden egészségügyi rendszer élt azzal a megoldással is, hogy önkéntesen jelentkező orvostanhallgatókat vontak be ápolási feladatok ellátására. Jellemző volt, hogy maguk a 
hallgatók is szervezeteket ${ }^{5}$ hoztak létre a COVID-19 járvány elleni védekezéssel járó feladatok megszervezésére és az önkéntesek koordinálására (Miller et al. 2020; Soled et al. 2020).

Magyarországon az orvos- és egészségtudományi tanulmányokat folytató hallgatók COVID-19 járvány alatti önkéntességének szervezése 2020 márciusában indult meg, párhuzamosan az online oktatásra való átállással. Az egészségügyi miniszteri körlevél ${ }^{6}$ megjelenése után, a négy orvos- és egészségtudományi képzést folytató egyetemen felálltak azok az operatív stábok ${ }^{7}$, amelyek a hallgatók önkéntességét koordinálták. Noha az Országos Kórházi Főigazgatóság regisztrációs honlapján ${ }^{8}$ az szerepelt, hogy a járvány elhárításában való közremúködés önkéntes jogviszony keretében, a közérdekű önkéntes tevékenységről szóló 2005. évi LXXXVIII. törvény rendelkezései alapján, ellenszolgáltatás nélkül történik, de az egyetemek különböző mértékben és módon (vagy ösztöndíjjal, illetve kreditként elismerve, ${ }^{9}$ vagy a szolgálati helytől kapott juttatással) ösztönözték hallgatóikat az önkéntes részvételre. Az önkéntesek munkaideje nem volt egységesen szabályozott, főként a fogadószervezet munkarendjétől függött (így előfordulhatott napi 5 órás, de 12 órás önkéntes szolgálat is). Az ellátott tevékenységek ${ }^{10}$ a gyakorlatban - a hallgatók tanulmányi felkészültségétől függetlenül - főként segédápolói ${ }^{11}$ vagy kiegészítő (felvételi, adminisztratív, logisztikai) feladatokat jelentettek.

A COVID-19 járvány második és harmadik hullámában a járványügyi politika súlypontja a kötelező kirendelés lett. ${ }^{12}$ Így 2020 szeptembere és 2021 áprilisa között, az orvos- és

\footnotetext{
${ }^{5}$ A Harvard Medical School orvostanhallgatói megalapították például a „COVID-19 Student Response Team” nevű csoportot, amely támogatta a kórházak, klinikák egészségügyi személyzetét a mindennapi életben, illetve aktivista, felvilágosító munkát végeztek a helyi közösségekben.

${ }^{6}$ Forrás: https://semmelweis.hu/hirek/files/2020/03/Dr.-Kásler-Miklós-levele.pdf 2020.03.16.

${ }^{7}$ Forrás: https://semmelweis.hu/hirek/2021/02/04/aterezzuk-a-feladat-sulyat-semmelweis-hallgatok-a-jarvanyelleni-vedekezesben/ 2021.02.04.

${ }^{8}$ Forrás: https://covid-onkentes.aeek.hu

${ }^{9}$ A harmad-negyed éveseknél a nyári gyakorlatba, hatodéveseknél a blokk-gyakorlatba számították bele.

${ }^{10}$ Az OKFÖ regisztrációs honlapja szerint (https://covid-onkentes.aeek.hu): „Az egészségügyi képzésben résztvevő önkéntes kollégákat elsősorban az alábbi feladatok ellátásával szeretnénk megbízni: a fertőzés gyanús és fertőzött betegek megfigyelése; a középsúlyos fertőzött betegek ellátásában való részvétel; a súlyos állapotban lévő fertőzött betegek intenzív ellátásában való részvétel; az időskorú betegek otthoni vagy intézeti ellátásában való részvétel; a fogyatékos embertársaink otthoni vagy intézeti ellátásában való részvétel; a karanténok valamelyik formájában lévő betegek ellátásában való részvétel."

11 Például: oxigénpalackok cseréje, gyógyszerelés, vércukor, vérnyomás, véroxigén-telítettség mérése, infúziók bekötése, étel- és italosztás, etetés-itatás, ágyazás, pelenkázás, inzulinok beadása a cukorbetegeknek étkezés előtt stb. Forrás: https://weborvos.hu/lapszemle/orvostanhallgatok-az-elso-vonalban-266139 2021.03.24.

${ }^{12}$ A 2020. november 19. -én megjelent 509/2020. Kormányrendelet elrendelte az orvos- és az egészségtudományi képzésben résztvevő hallgatók kötelező kirendelését a nevelési, oktatási, szociális intézményekben, illetve bölcsődékben dolgozók szűrésének idejére. Majd 2021. március 17-től kezdődően április végéig az orvosi és egészségtudományi tanulmányokat folytató hallgatók ismét kötelező vezénylés alatt álltak.
} 
egészségtudományi hallgatók vagy vezénylés alatt és/vagy önkéntesként vettek részt a járvány elleni védekezésben, illetve segítették a kórházak, klinikák és az Országos Mentőszolgálat munkáját. A 2021. februári kormányzati adatok szerint több mint ötezer hallgató vette ki részét a koronavírus-járvány elleni védekezésből. ${ }^{13}$

A nemzetközi szakirodalomban az önkéntes orvostanhallgatók COVID-19 járvány leküzdésében játszott szerepéről 2020 második felében jelentek meg az első, vitákat és gyakorlati tapasztalatokat feldolgozó esettanulmányok (például: Ahmed et al. 2020; Bukland 2020; Drexler et al. 2020; Glikman et al. 2020; Long et al. 2020; Miller et al. 2020; Riva et al. 2020; Soled et al. 2020). Ezeket követték 2021 elejétől fogva azok a tanulmányok, amelyek egy-egy ország, illetve egyetem orvostanhallgatóinak kérdőíves megkérdezésen alapultak, és különböző kutatási nézőpontból igyekeztek feltárni az orvostanhallgatók önkéntességének tapasztalatait és problémáit (Adjemi et al. 2021; Bazan et al. 2021; Byrne et al. 2021; Lazarus et al. 2021; Manraj et al. 2021; Michno et al. 2021; Shi et al. 2021)

Tanulmányunknak, amely Magyarországon először foglalkozik az orvos- és

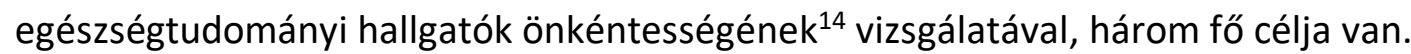

- Először is, az általunk vizsgált önkéntesség különleges körülmények között járványhelyzetben - és speciális önkéntes tevékenységként valósult meg, amit a szakirodalom a krízis vagy a katasztrófa önkéntesség kategóriájába sorol. Mindebből következően elsődleges célunk e speciális önkéntes tevékenység munkafeltételeinek, az arra való felkészítésnek és a szerzett tapasztalatoknak az elemzése.

- A magyar gyakorlatban az orvos- és egészségtudományi hallgatók pandémia alatti önkéntessége az önkéntes jogviszony alapján történt, de különböző juttattatások által ösztönzött volt. Ezért további fő célunk az önkéntes-elköteleződés, valamint az ezt befolyásoló ösztönzőknek a vizsgálata. Célunk az is, hogy feltárjuk az önkéntesség tartósságát meghatározó tényezők - az önkéntesség gyakorisága, illetve korábbi önkéntes tapasztalatok - szerepét a pandémia alatti önkéntesség vállalásában. Mindezek alapján azt kívánjuk megmutatni, hogy az önkéntesek nem alkottak homogén csoportot sem önkéntességük tartóssága, sem pedig önkéntes-elköteleződésük szerint.

\footnotetext{
13 https://unilife.hu/egyetem/20210204-a-hallgatok-is-aktivan-kuzdenek-a-jarvany-ellen.html

14 Terjedelmi korlátok miatt a jelen elemzésben nem térünk ki az általános orvos, fogorvos, gyógyszerész és egészségtudományi szakos hallgatók kirendelésével kapcsolatos eredmények ismertetésére, azokat majd egy későbbi tanulmányban mutatjuk be.
} 
- Végezetül célunk az is, hogy az önkéntesek különböző csoportjaiban elemezzük az önkéntesek e speciális csoportjának motivációt a Bartal - Kmetty (2011) által sztenderdizált Magyar Önkéntes Motivációs Kérdőív hét faktorának vizsgálatával. Ennek alapján differenciáltan láthatóvá válik, hogy a juttatások mellett még milyen motivációs tényezők hatottak a pandémia alatti önkéntesség vállalására.

Szerkezetileg tanulmányunk négy fő részből áll. Először ismertetjük a nemzetközi szakirodalmi elemzések alapján azokat az eredményeket, amelyek az orvostanhallgatók önkéntességének különböző aspektusait tárták fel a COVID-19 járvány első két hulláma alatt. Ezek az elemzések referenciapontul szolgálnak saját kutatásunk eredményeinek értékeléséhez is. A második részben a szakirodalomból levezethető és a kutatási célok által indukált fő kutatási kérdésekkel, valamint a hipotézisekkel foglalkozunk. Ezt követően bemutatjuk az elemzési mintát és a kutatás módszereit. A tanulmány negyedik részében kerül sor az eredmények ismertetésére, amelyeket a kutatási céloknak megfelelően három téma köré csoportosítva ismertetünk.

\section{NEMZETKÖZI KUTATÁSI EREDMÉNYEK AZ ORVOSTANHALLGATÓK ÖNKÉNTESSÉGÉRŐL A COVID-19 JÁRVÁNY ELSŐ ÉS MÁSODIK HULLÁMA IDEJÉN}

Az orvostanhallgatók világjárványok idején történő önkéntessége nem példa nélküli, hiszen már az 1918-as spanyolnátha idején a Pennsylvaniai Egyetem orvostanhallgatói segítettek a betegek ellátásában (Starr 1976). Dániában, 1952-ben, a gyermekbénulási járvány kitörésekor önkéntesen jelentkező orvostanhallgatók végezték a betegek kézi lélegeztetését (West 2005). Hasonlóképpen, a 2006-os H5N1 járvány idején az albertai (Herman et al. 2007; Rosychuk et al. 2008) és a 2009-es H1N1 járvány alatt pedig a michigani egyetem orvostanhallgatóit időlegesen bevonták a kórházi ápolási feladatokba (Waigt et al. 2011).

Az eddig megjelent, az orvostanhallgatók COVID-19 járvány alatti önkéntességéről szóló nemzetközi kutatási eredményeket két csoportra oszthatjuk. Amíg a 2020 második felében napvilágot látott tanulmányok még gyorsjelentések, esettanulmányok formájában a legelső tapasztalatokat rögzítették, addig a 2021-es tanulmányok már keresztmetszeti, főként nemzeti szintű, vagy egy-egy egyetem hallgatóinak kvantitatív módszerekkel történő vizsgálatán alapultak, differenciált kutatási tematika szerint. 


\section{Viták és első eredmények az orvostanhallgatók önkéntességéröl a COVID-19 pandémia kezdetén}

Az orvostanhallgatók önkéntességének problémáival foglalkozó legelső esettanulmányok egy része azt a polémiát járta körül - ami már az H5N1 influenzajárvány idején is felmerült ${ }^{15}$-, hogy milyen kockázatokat jelenthet az orvostanhallgatók járvány alatti önkéntessége: kompetencia problémák, megfertőződés, a fertőzés továbbadása a saját családban, a szúkös védőeszköz állomány „elhasználása”, illetve a klinikai munka valószínűsíthető stressz-hatása (Miller et al. 2020; Riva et al. 2020). Másik részük azt vitatta meg, hogy a pandémia első hullámában az egyes egészségügyi rendszerekbe miként és milyen formában - önkéntesség és/vagy részmunkaidős foglalkoztatás - valósítható meg optimálisan és differenciáltan az orvostanhallgatók bevonása (Drexler et al. 2020; Glikman 2020). Ehhez szorosan kapcsolódott azoknak a friss tapasztalatoknak az elemzése is, hogy mit jelentett az orvostanhallgatóknak különösen az elmaradt klinikai gyakorlatok szempontjából - az online képzésre való átállás és ennek milyen kihívásai, illetve jövőbeni hasznosítható eredményei mutatkoztak meg (Long et al. 2020; Soled et al. 2020).

Végezetül az első kvalitatív tanulmányok már az orvostanhallgatók önkéntességének a pandémia első hullámában tapasztalható eredményeit is regisztrálták. Az online kérdőíves felvételeken alapuló vizsgálatok szerint (például: Ahmed et al. 2020; Astrop et al. 2020; Drexler et al. 2020) az orvostanhallgatók többsége elkötelezettnek vallotta magát és hajlandó volt részt venni önkéntesként a pandémiás vészhelyzetben. Ugyanakkor, Drexler et al. (2020) kutatása - amelyet a Semmelweis Egyetem Hamburgi Kampuszára beiratkozott 219 harmadötödéves és végzős hallgatói körében végeztek - arra hívta fel a figyelmet, hogy a COVID-19 első hullámában csak a jelentkezők 25 százalékát fogadták a kórházak önkéntesként. A hallgatók többsége hasznosnak ítélte meg munkáját, és úgy érezte, hogy az egészségügyi személyzet értékeli azt. A korlátozott betegkontaktus, az ágy melletti oktatás csökkenése és a törölt gyakorlatok miatt a végzős hallgatók 87 százaléka arról számolt be, hogy klinikai

\footnotetext{
${ }^{15}$ Herman et al. (2007:1782) idézte azt a vitát, ami az orvostanhallgatók bevonását illetően bontakozott ki a kanadai egészségügyi kormányzatban. Az érvek egyik csoportja amellett szólt, hogy az orvostanhallgatókat ösztönözni kell önkéntes munkára válság idején, mert ez értékes orvosi képzést nyújthat. Az érvek másik csoportja szerint az orvosok következő generációjának önkéntesként történő élvonalba helyezése fokozottan veszélyeztetheti őket. Végül Health Canada az orvostanhallgatók erős önkéntes elköteleződése ellenére is úgy döntött, hogy visszarendeli őket a kórházi önkéntes szolgálatból.
} 
oktatásukra káros hatással volt COVID-19 világjárvány és pesszimisták voltak jövőbeli terveiket illetően.

Astorp et al (2020) felmérése három, a pandémia alatti önkéntességet befolyásoló motivációt azonosított az aalborgi egyetem 415 orvostanhallgatójának körében: az altruista („embertársaik megsegítése”), a tanulási lehetőség, valamint az elismerés motivációkat. Eredményeik szerint a klinikai tapasztalatokkal már rendelkező, potenciális önkéntesek körében növekvő prioritást kapott az önkéntesség ellentételezése, akár „fizetés” formájában is. Az önkéntességet befolyásoló külső tényezők közül a munkavégzés biztonságát tartották a legfontosabbnak válaszadóik, amit más, további vizsgálatok (Ahmed et al 2000; Michino et al. 2001; Sra et al. 2021) is kiemeltek.

Kvantitativ kutatási eredmények az orvostanhallgatók önkéntességéröl a COVID-19 járvány első két hulláma idején

Az egyetlen nemzetközi, online, de nem reprezentatív felmérés - 74 ország 760 hallgatójának válaszai alapján - azt kutatta, hogy az orvostanhallgatók miként látják saját szerepüket a COVID-19 elleni védekezésben (Michno et al. 2021). A válaszadók 71 százaléka nyilatkozott úgy, hogy hajlandó a COVID-19 világjárvány idején az egészségügyi személyzet részeként segíteni, ami a klinikai évfolyamok hallgatóira nagyobb valószínúséggel volt jellemző, mint a preklinikai évfolyamokéra. Több mint a felük (57 százalékuk) úgy gondolta, hogy önkéntességük idején szükséges a hivatalos munkaszerződés, és a klinikai környezetben végzett munkájukért pénzügyi díjazásban kellene részesülniük. A munkavégzés biztonságát az önkéntesség egyik feltételének tartották a nemzetközi minta válaszadói is. Önkéntességük akadályaként a fertőzéstől való félelmet, illetve családtagjaik veszélyeztetését 83 százalékuk jelezte. (Hasonló tapasztalatokról számolt be Ahmed et al. (2020) is a karacsi egyetem orvostanhallgatói körében végzett kutatásában).

A már 2021-ben megjelent tanulmányok egyike (Sra et al. 2021), Újdelhi Oktatókórházának 297 orvostanhallgatójának körében felvett vizsgálaton alapult. Főként a preklinikai és a klinikai orvostanhallgatók közötti különbségek megmutatására koncentrált a COVID-19 fertőzés ismereteinek mérésével, illetve a potenciális önkéntesek által preferált munka feltérképezésével. A szerzők szignifikáns különbséget találtak a klinikai és a preklinikai évfolyamok között, nem csak a COVID-19 ismeretét illetően, hanem az önkéntesség alatt preferált munka tekintetben is. A preklinikai évfolyamok hallgatói kevesebb és pontatlanabb 
tudással rendelkeztek a COVID-19-ről, és inkább a szociális, felvilágosító és közvetett klinikai munka iránt mutattak nagyobb hajlandóságot. Ugyanakkor a COVID-19 fertőzésről szélesebb ismeretekkel rendelkező klinikai évfolyamok hallgatói körében szignifikánsan magasabb volt a közvetlen klinikai munkában való részvétel szándéka.

Hasonló eredményekre jutott Adejimi et al. (2021) is, amikor a lagosi egyetem 411 orvos- és fogorvostan hallgatójának önkéntességgel kapcsolatos attitűdjeit igyekeztek feltárni. Elemzésük szerint az utolsó éves orvostanhallgatók nagyobb eséllyel jelentkeztek önkéntesnek, még ha ezért nem is kaptak kompenzációt, valamint a fiatalabb évfolyamok hallgatói ez esetben is inkább a közvetett klinikai munkát preferálták.

Témánk szempontjából ki kell emelni Lazarus et al. (2021) Indonézia összes egyetemének, 4870 preklinikai tanulmányokat folytató orvostanhallgatója körében felvett vizsgálatát. A szerzők azt találták, hogy - a nem, a hallgató családjának szocio-ökonómiai státusza, lakóhelye, valamint az egyetem típusa mellett - a korábbi önkéntes tapasztalat is jelentős szerepet játszott a járvány alatti önkéntesség vállalásában. Elemzésük szerint a férfiak, a magasabb jövedelmű családokból származók, a Közép-Indonéziában lakók (versus Java), az állami egyetemek és a (kórházi vagy nem kórházi) önkéntes tapasztalatokkal rendelkező hallgatók között szignifikánsan magasabb volt azok aránya, akik hajlandók voltak önkénteskedni a járvány első hullámában.

Az önkéntességet befolyásoló, illetve az azt megerősítő elismerésigény fontosságára mutatott rá Bazan et al. (2021) tanulmánya, a poznani egyetem 580, a COVID-19 járvány első hullámában (2020. március-szeptember között) önkéntesként szolgáló orvostanhallgató tapasztalatainak vizsgálatával. A szerzők szoros összefüggést írtak le a hallgatók önkéntességgel való elégedettsége és a barátok, egészségügyi dolgozók vagy más hallgatók felől érkező elismerés között. Az elégedettebb hallgatók tovább és hosszabb ideig folytatták önkéntességüket, átlagosan több munkaórát is teljesítettek. Ugyanakkor azok a hallgatók, akik nem kaptak pozitív visszajelzést, vagy negatív tapasztalatokat szereztek (például a betegkapcsolatok során, vagy az egészségügyi dolgozók részéről) lényegesen rövidebb volt az önkéntesség ideje és kevésbé voltak hajlandók további szolgálatot vállalni. A hallgatók válaszai alapján Bazan et al. (2021:5) három tényezőt azonosított, mint a COVID-19 járvány alatti önkéntesség közvetlen előnyeit: a szakmai tapasztalatszerzést, a segítségnyújtás érzését, valamint az együttműködési készség fejlesztését. 
A COVID-19 járvány következtében fokozott hangsúllyal vetődött fel annak vizsgálata, hogy miként lehet ösztönözni az orvostanhallgatókat az önkéntességre. Az orvostanhallgatók motivációinak vizsgálatánál (Zweigelhaft et al. 1996; Feltcher- Major 2004; Ferreira et al. 2012; Beck et al. 2015) mindig felmerül az a kérdés, hogy a feltárt motivációk mennyiben kontextusfüggők, illetve mennyiben mutatják az önkéntes munka iránti elköteleződést. Korábbi tanulmányukban Rovers et al. (2016) azt találták, hogy az általuk vizsgált orvostanhallgatók önkéntes-motivációi sokkal inkább szolgálatuk orvosi hátteréhez kapcsolódott, mint az önkéntes munka eredendő vágyához.

Ezért Shi et al. (2021) azt kutatták, hogy az önkéntességet mint proszociális magatartást az orvostanhallgatók körében milyen tényezők befolyásolják a COVID-19 járvány idején. A tíz kínai tartományban felvett 2454 érvényes válasz alapján azt mutatták ki, hogy a járványhelyzet „stimulálólan” hatott a dominánsan altruista motivációjú hallgatókra, akiket a félelem nélküli áldozat- és a felelősségvállalás, az önzetlenség, szolidaritás és a reciprocitás jellemzett. Ezen hallgatók csoportja kifejezte, hogy tartósan részt kíván venni önkéntes szolgálatokban. A szerzők szerint a karrier és a társadalmi felelősségvállalás motivációk közvetítő szerepet játszanak az önkéntességnek, mint proszociális magatartásnak a kialakulásban, és állást foglaltak amellett, hogy az orvosi oktatásban nagyobb figyelmet kell kapnia a társadalmi felelősségvállalásra és az önkéntesség gyakorlására való felkészítésnek. Ezért a hallgatóknak olyan munkalehetőségeket lenne célszerű felkínálni, amelyek hozzájárulnak az önkéntes, szolgálati tanulásukhoz.

\section{A KUTATÁS KÉRDÉSEI ÉS HIPOTÉZISEI}

A COVID-19 járvány első és második hulláma alatt végzett nemzetközi kutatások még az orvostanhallgatók önkéntességre való hajlandóságát vizsgálták. Hazai, retrospektív kutatásunk viszont a pandémia harmadik hullámának végén készült, ezért egyik fő kérdésünk, hogy milyen volt az önkéntes-elköteleződés a vizsgálatunkban résztvevő, pandémia alatt önkéntességet vállaló 395 orvos- és egészségtudományi hallgató körében. További kérdésünk, hogy ezt az önkéntes-elköteleződést mennyiben befolyásolták az egyetemektől és a fogadóintézményektől kapott ösztönzők. A szakirodalmi eredmények alapján (Astorp et al. 2021; Michno et al. 2021; Sra et al. 2021) azt feltételeztük, hogy a preklinikai (első és harmadévesek) és a klinikai (negyed-hatodévesek) évfolyamok hallgatói között eltérések várhatók a 
tekintetben, hogy az ösztönzők miként befolyásolták önkéntes-elköteleződésüket. Eszerint azt várjuk, hogy a klinikai évfolyamok hallgatói elkötelezettebbnek mutatkoznak majd önkéntességükben, mint a preklinikiai évfolyamokéi, mivel az (anyagi) ösztönzők kevésbé játszanak szerepet önkéntességük vállalásában.

A kutatásunk másik fő kérdése, hogy a válaszadók mennyire alkottak differenciált csoporto(ka)t a pandémia alatti önkéntes tevékenységük jellemzői alapján. Az önkéntességgel foglalkozó szakirodalmi eredmények (Hustinx 2001; Hustinx - Lammertyn 2003; Hustinx et al. 2008; Bartal - Kmetty 2011; Fényes 2015; Hyde et al. 2016) szerint a korábbi önkéntes tapasztalatok, valamint az önkéntesség gyakorisága és rendszeressége szerint az önkéntesek különböző jellemzókkel írhatók le. Úgy véltük, hogy ezen kritériumok mentén a pandémia alatti orvos- és egészségtudományi szakos önkéntes hallgatók is csoportosíthatók. Azt is feltételeztük, hogy ezek a csoportok különböznek majd nemcsak a kontextuális változók mentén, hanem motivációikban is. Astorp et al. (2021) és Shi et al. (2021) alapján úgy véltük, hogy az altruista motivációk (érték motivációs faktor), a tanulási tapasztalatok (megértés motivációs faktor) és az elismerés (önbecsülés motivációs faktor) lesznek, - ha különbözőképpen is - a meghatározó motivációk a pandémia alatti önkéntesek csoportjaiban. Végezetül, az önkéntesek motivációi és az önkéntes-elköteleződés kapcsolatát tekintve úgy véltük, hogy általánosságban, a pandémia alatt rendszeresen önkénteskedők és a korábbi önkéntes tapasztalatokkal rendelkezők lesznek a legmotiváltabbak. Dorner (2013) szakirodalmi összegzése alapján úgy gondoltuk, hogy az önkéntes-elköteleződés független lesz attól, hogy az altruizmus, társadalmi-szociális értékek (mint belső motivációk), vagy az elismerés, készségfejlesztés, karrierépítés (mint külső motivációk) vezérlik-e leginkább az önkénteseket.

\section{A KUTATÁS ADATFORRÁSAI ÉS MÓDSZEREI}

Tanulmányunk fő kérdéseinek megválaszolásához és hipotéziseinek igazolásához az általános orvos, fogorvos, gyógyszerész és egészségtudományi szakos hallgatók körében felvett kérdőíves vizsgálat szolgált adatforrásul. A kérdőíves felmérésre 2021. április 11. és május 6. között került sor, egy webalapú (Google Forms) kérdőív alkalmazásával. ${ }^{16}$ A kérdőív

\footnotetext{
${ }^{16}$ A kérdőív elején a vizsgálat céljáról szóló tájékoztatás szerepelt és a kérdőív csak akkor jelent meg, ha a hallgató beleegyezését adta, hogy a kutatásban önként vesz részt és hozzájárul, hogy válaszait anonimizáltan kutatási
} 
összeállítása előtt háttérinterjúkat folytattunk az egyetemek HÖK vezetőivel. A kérdőív öt nagy kérdéskört tartalmazott, 52 kérdés formájában, úgy mint:

- Szociodemográfiai adatok.

- A pandémiát megelőző időszak önkéntességére vonatkozó kérdések.

- A pandémia alatti önkéntesség, az önkéntes munkavégzés körülményeinek, továbbá az önkéntességgel kapcsolatos állításoknak az értékelése, valamint a pozitív és negatív tapasztalatokra vonatkozó kérdések.

- Az önkéntes motivációkra vonatkozó állítások értékelése a MÖMK (Bartal - Kmetty 2011) érték, elismerés, reciprocitás, önbecsülés, karrier, megértés, kormányzati elégtelenség motivációs faktorok itemjei alapján.

- A COVID-19 járvány második és első hullámában történő kirendelések alatti munkavégzés körülményeinek, valamint a kirendeléssel kapcsolatos állítások értékelése, illetve a kirendeléssel kapcsolatos pozitív és negatív tapasztalatokra vonatkozó kérdések.

A webalapú kérdőívet a négy magyarországi általános orvos, fogorvos és gyógyszerész, valamint egészségtudományi szakokkal rendelkező egyetemek hallgatóinak hólabda módszerrel küldtük el, illetve a közösségi médiában hirdettük meg. Összesen 560 érvényes válasz érkezett be. Ez a nem reprezentatív válaszadói minta a kormányzati kommunikációban megjelenő ${ }^{17}$ önkéntesszám mintegy 10 százalékának felelt meg.

Jelen tanulmány kutatási mintáját az a 395 (a teljes minta 70,5 százaléka) válaszadó alkotja, aki 2020. március és 2021. április közötti időszakban önkéntes volt.

A pandémia alatti önkéntesek mintájába bekerült - általános orvos, fogorvos, gyógyszerész egészségtudományi szakos - válaszadók 75 százaléka nő, közel háromnegyedük egyedülálló, döntő többségük gyermektelen, átlagéletkoruk pedig 24,67 év (SD= 2,78) (1. táblázat). Lakóhelyük szerint a fővárosi - vidéki lakosok aránya 25-75 százalék. A Semmelweis Egyetem hallgatói közül került ki a válaszadók egyharmada, míg a többi három egyetemről - a Debreceni Egyetemről, a Pécsi Tudományegyetemről és a Szegedi Tudományegyetemről azonos arányban (21-23 százalék) voltak válaszadók.

célra felhasználják és azokból elemzéseket készítsenek. A GDPR megfelelést a Társadalomtudományi Kutatóközpont ellenőrizte.

${ }^{17}$ https://unilife.hu/egyetem/20210204-a-hallgatok-is-aktivan-kuzdenek-a-jarvany-ellen.html 2021.02.05. 
1.táblázat A 2020. március és 2021. április között önkéntes, általános orvos, fogorvos, gyógyszerész egészségtudományi szakos, hallgatók válaszadói mintájának jellemzői

\begin{tabular}{|c|c|c|}
\hline \multicolumn{2}{|c|}{ Szociodemográfiai és kontextuális változók } & \multirow{2}{*}{$\begin{array}{l}\text { Covid-19 járvány alatti } \\
\text { (2020. március - 2021. április) } \\
\text { önkéntesek mintája } \\
\mathrm{N}=395\end{array}$} \\
\hline \multirow[t]{2}{*}{ Nem } & férfi & \\
\hline & nő & 296 fö (75\%) \\
\hline \multicolumn{2}{|c|}{ Átlagéletkor } & 24,67 év SD=2,78 \\
\hline \multirow[t]{3}{*}{ Családi állapot } & nőtlen/hajadon & 280 fö (71\%) \\
\hline & élettársi kapcsolatban él & 105 fő (27\%) \\
\hline & házas & 10 fő (2\%) \\
\hline \multirow[t]{3}{*}{ Gyermekek száma } & nincs gyermek & 392 fö $(99,2)$ \\
\hline & 1 gyermek & 1 fö $(0,3 \%)$ \\
\hline & 2 gyermek & 2 fö $(0,5 \%)$ \\
\hline \multirow[t]{4}{*}{ Lakóhely } & fóváros & 92 fö (25\%) \\
\hline & megyeszékhely & 132 fö (35\%) \\
\hline & város & 100 fö (27\%) \\
\hline & község & 50 fö (13\%) \\
\hline \multirow[t]{4}{*}{ Intézmény } & Debreceni Egyetem & 92 fö (23\%) \\
\hline & Pécsi Tudományegyetem & 89 fö (23\%) \\
\hline & Semmelweis Egyetem & 129 fö (33\%) \\
\hline & $\begin{array}{c}\text { Szegedi } \\
\text { Tudományegyetem }\end{array}$ & 85 fö (21\%) \\
\hline \multirow[t]{4}{*}{ Szak } & ÁOK & 175 fö (44\%) \\
\hline & ETK & 181 fö (46\%) \\
\hline & GYTK & 31 fö ( $8 \%)$ \\
\hline & FOK & 8 fö ( $2 \%)$ \\
\hline \multirow[t]{7}{*}{ Évfolyam } & 1. évfolyam & 64 fö (16\%) \\
\hline & 2. évfolyam & 85 fő (21\% \\
\hline & 3. évfolyam & 86 fö (22\%) \\
\hline & 4. évfolyam & 87 fö (22\%) \\
\hline & 5. évfolyam & 39 fö (10\%) \\
\hline & 6. évfolyam & 32 fö $(8 \%)$ \\
\hline & rezidens & 2 fő ( $1 \%)$ \\
\hline
\end{tabular}

Forrás: saját szerkesztésű táblázat adatbázis alapján

Az önkéntesek válaszadói mintájában az egészségtudományi és az általános orvos hallgatók közel azonos arányban (46-44 százalék) kerültek be. Ezért a részletesebb elemzéseknél az áltanos orvos és egészségtudományi szakos hallgatókra vonatkoztatva fogalmazzuk meg 
állításainkat, mivel a fogorvos, gyógyszerész válaszadóknak alacsony (39fő) volt a mintabeli elemszámuk.

Az évfolyamok szerinti megoszlást nézve, az általános orvos önkéntes hallgatók között a preklinikai - klinikai évfolyamba tartozók aránya 42-58 százalék (74, illetve 101 fő), míg az egészségtudományi szakos hallgatók között az első - másod, illetve a harmad - negyedévesek aránya 54-46 százalék (97, illetve 84 fő). A pandémia alatt önkéntesek válaszadói mintáját tehát az általános orvostanhallgatók közül inkább a klinikai évfolyamok, míg az egészségtudományi hallgatók közül inkább az első két évfolyam hallgatói határozzák meg.

A pandémia alatti önkéntesek mintájának négy alcsoportra bontása két változó mentén történt: a korábbi önkéntes tapasztalat (igen-nem) és a pandémia alatti önkéntesség gyakorisága szerint, azaz 2020. március és 2021. április között egy időszakban vagy több időszakban volt-e önkéntes. A minta válaszadóinak 35 százaléka (138 fő) volt önkéntes a pandémia előtt, míg 65 százalékuk (257 fő) nem volt önkéntes. A pandémia alatt egy időszakban ${ }^{18}$ összesen 39 százalékuk (154 fő) volt önkéntes, míg 61 százalékuk (241fő) több időszakban önkénteskedett.

Az önkéntesség körülményeit és az önkéntes-tipológiát alapmegoszlások alapján, míg ezek összefüggéseit a szociodemográfiai és a különböző kontextuális változókkal (intézmény, szak, évfolyam-csoportok, az önkéntesség rendszeressége, az önkéntesség helye és a kódolt pozitív és negatív tapasztalatok) kereszttábla elemzés alapján mutatjuk meg. A motivációk vizsgálatát az átlag és szórás alapján végezzük, és az összefüggések vizsgálatához varianciaanalízist használunk.

\section{A PANDÉMIA ALATTI ÖNKÉNTESSÉG KÖRÜLMÉNYEI ÉS TAPASZTALATAI}

Azok az orvos- és egészségtudományi hallgatók, akik a pandémia három hullámában teljesítettek önkéntes szolgálatot, a 2005. évi LXXXVIII., közérdekú önkéntes tevékenységről szóló törvény alapján jogviszonnyal rendelkező önkéntesek voltak.

A munkavégzés biztonságát nézve, az önkéntesek döntő többsége (94 százaléka), úgy nyilatkozott, hogy az önkéntessége ideje alatt kapott mind védőruhát, mind pedig

\footnotetext{
${ }^{18} \mathrm{Az}$ önkéntesség időszakait a járvány három hullámának időszaka szerint határoztuk meg, tehát: 2020. márciusaugusztus; 2020. szeptember-december; 2021. január-április.
} 
védőfelszerelést. Természetbeni juttatásban (étkezés) 88 százalékuk részesült, míg ideiglenes szállást 44 százalékuk kapott, főként a vidéki önkéntesek.

Ugyancsak döntő többségük, 91 százalékuk válaszolta azt, hogy az önkéntesség megkezdése előtt részesült felkészítésben a járványhelyzetről, a védekezésről és az ellátandó feladatokról. A felkészítés jellege igen különböző volt: a válaszadók többsége (57 százalékuk) rövid egy órás, 19 százalékuk hosszabb, többórás felkészítést, míg 13 százalékuk a felkészítés mellé betanítást is kapott. Tizenegy százalékuk mondta azt, hogy semmilyen felkészítést nem kapott önkéntessége megkezdése előtt.

A pandémia alatt az önkéntesek 46 százaléka az OMSZ-nél, 43 százaléka kórházban, klinikán, míg 9 százaléka kórházban, klinikán és az OMSZ-nél is, és végül 2 százalékuk kizárólag civil, karitatív szervezetnél töltötte önkéntességét.

Összességében megállapítható, hogy az általunk vizsgált, a pandémia alatt önkéntes, orvos- és egészségtudományi hallgatók munkafeltételei (védőruha, védőfelszerelés, felkészítés) megfeleltek a járvány idején elvárható biztonsági feltételeknek. Válaszaik alapján gyenge szignifikáns összefüggést ${ }^{19}$ lehetett kimutatni az önkéntesként ellátott feladatokra való felkészítés jellege és az önkéntesség helye között. Ugyanis, a kórházakban önkéntes szolgálatot teljesítők többnyire csak rövid, míg az OMSZ-nél hosszabb felkészítést és betanítást is kaptak. Ez azért is figyelemre méltó, mert a kórházakban és klinikákon többségükben a preklinikai és az egészségtudományi szakos első és másodéves hallgatók végeztek önkéntes munkát, és a hiányos felkészítésüket - ahogy majd alább láthatjuk -, önkéntességük egyik negatív tapasztalatának élték meg.

Nyitott kérdésben arra kértük a válaszadókat, hogy írják meg legfontosabb pozitív és negatív tapasztalatukat a járvány alatti önkéntességükről. A 395 orvos- és egészségtudományi szakos hallgató közül 41 százalékuk írt a pozitív és 36 százalékuk a negatív tapasztalatairól ( 2 . táblázat). A pozitív tapasztalatok közül legtöbb említést kapott a betegek, munkatársak részéről érkező elismerés, megbecsülés (44 százalékban), valamint a szakmai tapasztalat, a személyiségfejlődés, és a kapcsolatok kialakítása (37 százalékban).

\footnotetext{
${ }^{19} \mathrm{p}=0,001 ;$ Cramer's V=0,231
} 
2. táblázat Az általános orvos- és egészségtudományi szakos hallgatók pandémia alatti önkéntességének pozitív és negativ tapasztalatai (az említések százalékában)

\begin{tabular}{|c|c|c|c|}
\hline \multicolumn{2}{|c|}{$\begin{array}{c}\text { Az önkéntesség pozitív tapasztalatai } \\
\text { Összesen: } 161 \text { említés }\end{array}$} & \multicolumn{2}{|c|}{$\begin{array}{c}\text { Az önkéntesség negatív tapasztalatai } \\
\text { Összesen: } 141 \text { említés }\end{array}$} \\
\hline $\begin{array}{c}\text { megbecsülés, elismerés } \\
\text { (a betegek és a munkatársak } \\
\text { részéről) }\end{array}$ & $44 \%$ & $\begin{array}{c}\text { szervezetlenség } \\
\text { (munkaszervezés, önkéntes- } \\
\text { fogadó helyek felkészültsége) }\end{array}$ & $29 \%$ \\
\hline $\begin{array}{l}\text { tapasztalat, szakmai és } \\
\text { személyiségfejlődés, } \\
\text { kapcsolatok kialakítása }\end{array}$ & $37 \%$ & $\begin{array}{l}\text { negatív kapcsolatok (betegek, } \\
\text { munkatársak részéről) }\end{array}$ & $26 \%$ \\
\hline közösség, csapatélmény & $14 \%$ & $\begin{array}{c}\text { (külső-belső) stressz, trauma } \\
\text { megélése }\end{array}$ & $23 \%$ \\
\hline a segítés, altruizmus megélése & $5 \%$ & $\begin{array}{l}\text { nem megfelelő körülmények és } \\
\text { felkészítés }\end{array}$ & $23 \%$ \\
\hline
\end{tabular}

Forrás: saját szerkesztésű táblázat adatbázis alapján

Negatív tapasztalatok közül a legnagyobb arányban a szervezetlenséget emíltették, a problémás beteg- és munkatársi kapcsolatok mellett. Azonos volt a külső (tanulmányi kötelezettségek teljesítése, túlterheltség), valamint a belső stressz (halál feldolgozása, félelem a megfertőződéstől és a fertőzés továbbadásától), illetve a nem megfelelő felkészítés és körülmények, mint negatív tapasztalatok említése (2. ábra).

3. táblázat A pandémia alatti önkéntesség legtöbbet emlitett pozitív és negatív tapasztalatai szakonként és évfolyamcsoportonként

\begin{tabular}{|c|c|c|}
\hline Szakok és évfolyamcsoportok & $\begin{array}{l}\text { Pozitív tapasztalatok } \\
\text { (legtöbb említés) }\end{array}$ & $\begin{array}{l}\text { Negatív tapasztalatok } \\
\text { (legtöbb említés) }\end{array}$ \\
\hline $\begin{array}{c}\text { Általános Orvostudományi Kar } \\
\text { hallgatói }\end{array}$ & $\begin{array}{l}\text { betegek megbecsülése, } \\
\text { szakmai tapasztalat }\end{array}$ & $\begin{array}{c}\text { munkaszervezés } \\
\text { problémás betegkapcsolatok } \\
\text { belső stressz }\end{array}$ \\
\hline $\begin{array}{l}\text { Egészségtudományi Kar } \\
\text { hallgatói }\end{array}$ & $\begin{array}{c}\text { munkatársak megbecsülése } \\
\text { szakmai tapasztalat }\end{array}$ & $\begin{array}{c}\text { munkaszervezés } \\
\text { problémás munkatársi } \\
\text { kapcsolatok } \\
\text { külső stressz }\end{array}$ \\
\hline $\begin{array}{c}\text { ÁOK preklinikai évfolyamok } \\
\text { hallgatói }\end{array}$ & szakmai tapasztalat & $\begin{array}{c}\text { fogadóhelyek szervezetlensége } \\
\text { problémás betegkapcsolatok } \\
\text { nem megfelelő felkészítés }\end{array}$ \\
\hline $\begin{array}{c}\text { ÁOK klinikai évfolyamok } \\
\text { hallgatói }\end{array}$ & betegek megbecsülése & $\begin{array}{c}\text { munkaszervezés } \\
\text { problémás munkatársi } \\
\text { kapcsolatok }\end{array}$ \\
\hline $\begin{array}{l}\text { ETK első-másodéves } \\
\text { hallgatók }\end{array}$ & munkatársak megbecsülése & $\begin{array}{c}\text { fogadóhelyek szervezetlensége } \\
\text { problémás betegkapcsolatok } \\
\text { nem megfelelő felkészítés }\end{array}$ \\
\hline $\begin{array}{c}\text { ETK harmad-negyedéves } \\
\text { hallgatók }\end{array}$ & szakmai tapasztalat & $\begin{array}{c}\text { munkaszervezés } \\
\text { problémás munkatársi } \\
\text { kapcsolatok }\end{array}$ \\
\hline
\end{tabular}

Forrás: saját szerkesztésű táblázat adatbázis alapján 
A legtöbbet említett pozitív és a negatív tapasztalatok jellegzetes különbségeket mutattak mind szakonként, mind pedig évfolyamonként (3. táblázat). Az orvostanhallgatók, de különösen a klinikai évfolyamok számára - a szakmai tapasztalat mellett - a betegek megbecsülése volt a legnagyobb arányban említett pozitív tapasztalat, míg az egészségtudományi szakos hallgatók, közülük is a felsőbb évfolyamok, illetve a preklinikai hallgatóknak a munkatársak megbecsülése jelentett pozitív tapasztalatot önkéntességük alatt. Sokkal többrétűnek mutatkozott a negatív tapasztalatok említése. Kiemelendő, hogy az alsóbb évfolyamok hallgatói közül leginkább a fogadóhelyek szervezetlenségét, a nem megfelelő felkészítést, míg a felsőbb évfolyamok hallgatói a munkaszervezést kifogásolták. Figyelemre méltó az is, hogy míg a felsőbb orvostanhallgatók többet említették a negatív betegkapcsolatokat, addig az egészségtudományi szakos harmad és negyedéves hallgatók a munkatársi kapcsolatok terén említettek negatív tapasztalatokat.

\section{ÖNKÉNTES-ELKÖTELEZŐDÉS A PANDÉMIA IDEJÉN}

Ahogy már fentebb említettük, kutatásunk a pandémia harmadik hulláma idején végzett, retrospektívnek mondható felmérés volt, és ezért az önkéntes-elköteleződés vizsgálatát helyeztük a fókuszba. Az Önkéntes törvény megenged bizonyos ellentételezéseket az önkéntes munkáért (például étkezés biztosítását, utazás, szállásköltségek térítését, valamint jutalmat). ${ }^{20} \mathrm{~A}$ magyar orvos- és egészségtudományi hallgatók pandémia alatti önkéntessége különböző juttatásokkal ösztönzött önkéntesség volt. Ezért az önkéntes-elköteleződésüket egyrészt az ösztönzők fontosságán, másrészt a pandémia alatti önkéntesség gyakorisága, harmadrészt pedig a korábbi önkéntes tapasztalatokon keresztül igyekeztünk feltárni.

\section{Az ösztönzők hatása a pandémia alatti önkéntességre}

Az önkéntes-elköteleződést egyfelől az „Akkor is önkénteskedtem volna, ha nem kapok juttatást érte" állítással (5 pontos Likert-skálán) való egyetértéssel mértük. Az eredmények szerint a válaszadó önkéntesek 57 százaléka egyetértett ezzel az állítással, azaz esetükben a juttatások nem játszottak kizárólagos szerepet az önkéntesség vállalásában. Ennek alapján azt mondhatjuk róluk, hogy rendelkeztek egyfajta „érdeknélküli” önkéntes-elköteleződéssel.

\footnotetext{
20 Ennek éves összege nem haladja meg a kötelező legkisebb munkabér mindenkori havi összegének húsz százalékát.
} 
Ugyanakkor 24 százalékuk bizonytalan volt annak megítélésében, hogy juttatás nélkül is vállalta volna a pandémia alatti önkéntességet, míg 19 százalékuk nem értett ezzel egyet. Az önkéntesek közel egyötöde számára tehát, az (anyagi) ösztönzők meghatározónak mutatkoztak önkéntességük vállalásában. Ahogy a 4. táblázat alapján látható, az „érdeknélküli” önkéntes-elköteleződés nagyobb aranyában (61 százalék) volt jellemző az orvostanhallgatókra, mint az egészségtudományi szakosokra (54 százalék). Kiemelendő, hogy az (anyagi) ösztönzők önkéntességet befolyásoló szerepét leginkább a klinikai évfolyamok hallgatói utasítottak el.

4. táblázat Az általános orvos és az egészségtudományi szakos hallgatók önkéntes-elköteleződésének mutatói szakonként és évfolyamonként (százalékban)

\begin{tabular}{|c|c|c|c|c|c|c|}
\hline & \multicolumn{3}{|c|}{$\begin{array}{c}\text { „Akkor is önkénteskedtem volna, ha } \\
\text { nem kapok díjazást érte." }\end{array}$} & \multicolumn{3}{|c|}{$\begin{array}{l}\text { „Szükségem volt az önkéntességért } \\
\text { kapott pénzre.” }\end{array}$} \\
\hline & egyetért & bizonytalan & $\begin{array}{c}\text { nem ért } \\
\text { egyet }\end{array}$ & egyetért & bizonytalan & $\begin{array}{c}\text { nem ért } \\
\text { egyet }\end{array}$ \\
\hline $\begin{array}{l}\text { Önkéntesek mintája } \\
(\mathrm{N}=395)\end{array}$ & $57 \%$ & $24 \%$ & $19 \%$ & $54 \%$ & $21 \%$ & $25 \%$ \\
\hline ÁOK (N=175) & $61 \%$ & $23 \%$ & $16 \%$ & $47 \%$ & $23 \%$ & $30 \%$ \\
\hline ETK $(\mathrm{N}=181)$ & $54 \%$ & $26 \%$ & $20 \%$ & $59 \%$ & $22 \%$ & $19 \%$ \\
\hline $\begin{array}{l}\text { ÁOK 1-3 évfolyam } \\
(\mathrm{N}=74)\end{array}$ & $60 \%$ & $19 \%$ & $21 \%$ & $48 \%$ & $27 \%$ & $25 \%$ \\
\hline $\begin{array}{l}\text { ÁOK 4-6 évfolyam } \\
\qquad(\mathrm{N}=101)\end{array}$ & $61 \%$ & $26 \%$ & $13 \%$ & $46 \%$ & $20 \%$ & $34 \%$ \\
\hline $\begin{array}{l}\text { ETK 1-2 évfolyam } \\
(\mathrm{N}=97)\end{array}$ & $55 \%$ & $25 \%$ & $20 \%$ & $60 \%$ & $21 \%$ & $19 \%$ \\
\hline $\begin{array}{l}\text { ETK 3-4 évfolyam } \\
\qquad(\mathrm{N}=84)\end{array}$ & $54 \%$ & $26 \%$ & $20 \%$ & $57 \%$ & $23 \%$ & $20 \%$ \\
\hline
\end{tabular}

Forrás: saját szerkesztésű táblázat adatbázis alapján

Másfelől, ismert tény, hogy az önkéntesség vállalását az egzisztenciális helyzet is nagyban befolyásolja. Ezért arra kértük a válaszadókat, hogy fejezzék ki (5 pontos Likert-skálán) mennyire értenek egyet azzal az állítással, hogy: „Szükségem volt az önkéntességért kapott pénzre." Az önkéntesek 54 százaléka egyetértett az állítással, azaz számukra a járvány alatti önkéntesség vállalásában egzisztenciális okok is szerepet játszottak. A bizonytalanok aránya 21 százalék volt, de 25 százalékuk az állítással egyet nem értők közé tartozott, azok közé, akiknek nem volt szükségük az önkéntességért kapott anyagi ösztönzőkre. A részletesebb elemzések szerint a klinikai évfolyamok hallgatói ennél magasabb arányban (34 százalékuk) értettek egyet azzal, hogy nem volt szükségük az önkéntességért kapott anyagi juttatásokra, 
míg az egészségtudományi szak első két évfolyamának hallgatói között csak 19 százalékuk vallotta ugyanezt (4. táblázat).

A két, anyagi ösztönzőkre vonatkozó változó közötti közepesen erős szignifikáns összefüggés ${ }^{21}$ azt az evidenciát támasztja alá, hogy azok voltak az „érdeknélküli” elkötelezettebb önkéntesek a pandémia alatt, akiknek önkéntességét nem befolyásolták a juttatások. Ez az önkéntesek mintájának 20 százalékára bizonyult igaznak, míg 13 százalékuk önkéntességét kifejezetten az anyagi ösztönzők mozgatták. Többségük (67 százalékuk) önkéntes-elköteleződése kevert típusúnak volt mondható, mert vagy „érdeknélküliségük” vagy pedig egzisztenciális helyzetük miatt mutatkoztak bizonytalannak.

Az eredmények értelmezéséhez figyelembe kell még venni, hogy a válaszadók 57 százaléka mondta azt, hogy a HÖK-től ösztöndíjat, 53 százalékuk a HÖK-től juttatást, 44 százalékuk pedig az intézménytől kapott díjazást, ahol önkéntes volt. Egyharmaduk a HÖK mindkét fajta juttatásában, és 23 százalékuk a HÖK támogatás mellett intézményi díjazásban is részesült. A válaszadók közel egyharmada tehát, minden ösztönző forrást igyekezett megszerezni, míg egyötödük semmilyen juttatásban nem részesült bevallása szerint. Ez utóbbi eredmény megegyezik az „érdeknélküli” legelkötelezettebb önkéntesek arányával.

\section{A COVID-19 pandémia alatti önkéntesség gyakorisága}

A pandémia alatti önkéntesség gyakoriságát vizsgálva látható (1. ábra), hogy az összes válaszadó 61 százaléka (241fő) több időszakban volt önkéntes, míg 39 százalékuk (154fő) csak egy időszakban (közülük legtöbben - 58 százalékuk - inkább a COVID-19 harmadik hullámában) teljesített önkéntes szolgálatot. Kiemelendő, hogy klinikai hallgatók 83 százaléka a pandémia három hulláma alatt több időszakban volt önkéntes.

A pandémia alatti önkéntesség gyakoriságában az általános orvos- és az egészégtudományi szakosok között gyenge ${ }^{22}$, a preklinikai és a klinikai évfolyamok között erős ${ }^{23}$ szignifikáns különbséget lehetett kimutatni. Ezek szerint az általános orvos és a klinikai évfolyamok hallgatói több időszakban voltak önkéntesek a pandémia három hulláma alatt, mint az egészségtudományi szakos, illetve a preklinikai évfolyamok hallgatói.

\footnotetext{
${ }^{21} \mathrm{p}=0,001 ;$ Cramer'sV=0,266

$22 \mathrm{p}=0,002 ;$ Cramer's $\mathrm{V}=0,156$

${ }^{23} \mathrm{p}=0,001 ;$ Cramer'sV=0,317
} 
1.ábra Az önkéntesség gyakorisága a pandémia alatt (szakonként és évfolyamcsoportonként, százalékban)

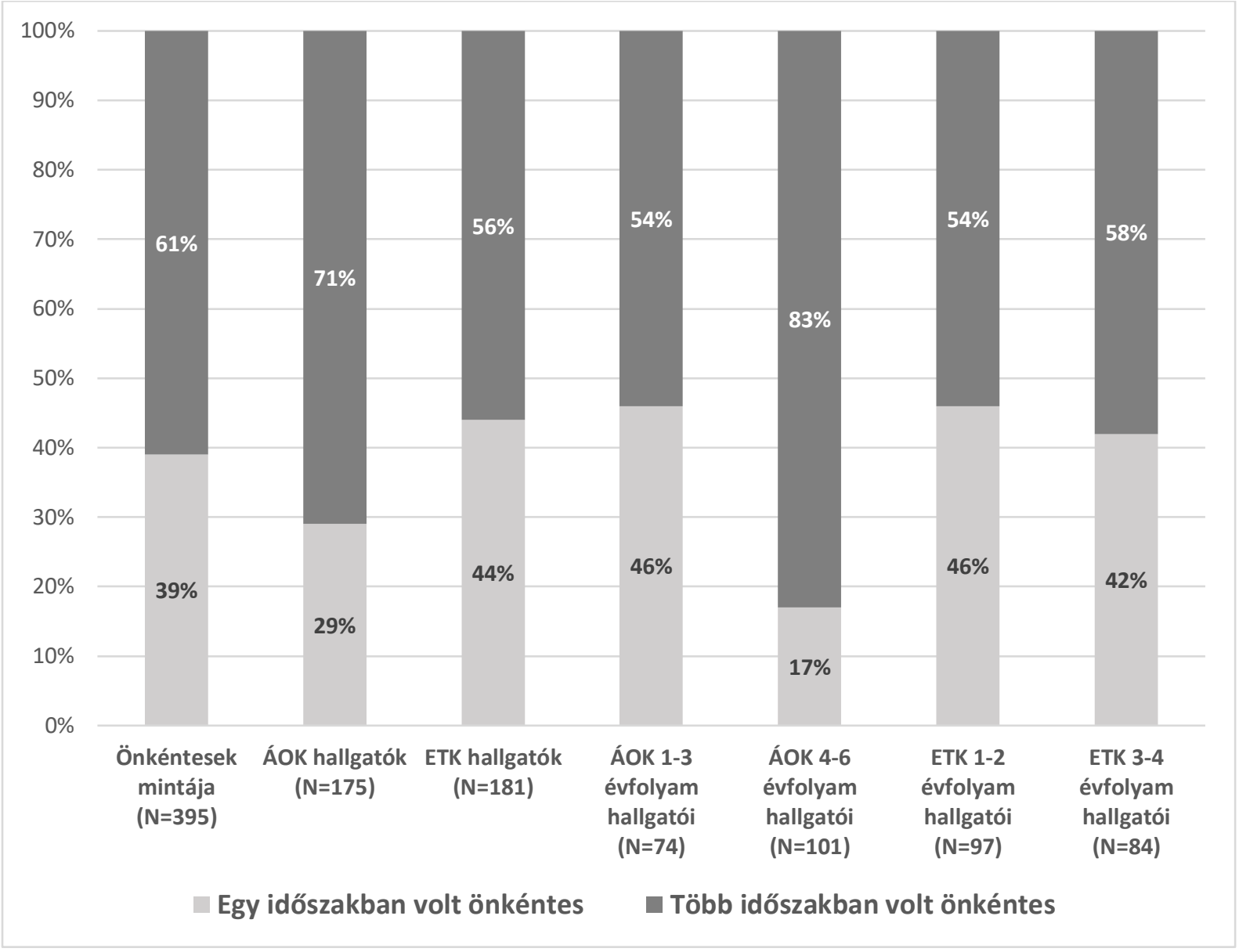

Forrás: saját szerkesztésű ábra adatbázis alapján

Ugyanakkor, az egészségtudományi évfolyamok önkéntességének gyakorisága nem mutatott szignifikáns eltérést, de a felsőbb évfolyamok hallgatói körében négy százalékkal magasabb volt a több időszakban önkéntesek aránya (1. ábra).

A részletesebb elemzés szerint a pandémia alatti önkéntesség gyakorisága és rendszeressége között gyenge szignifikáns összefüggés ${ }^{24}$ volt kimutatható. Azok az önkéntesek, akik több időszakban vállaltak önkéntességet, azok ezt rendszeresen tették meg, míg azok, akik csak egy időszakban voltak önkéntesek, inkább alkalmilag vagy epizodikusan teljesítettek önkéntes szolgálatot.

\footnotetext{
${ }^{24} p=0,006 ;$ Cramer'sV=0,172
} 


\section{A COVID-19 pandémia előtti önkéntes tapasztalatok}

A COVID-19 járvány alatt önkéntesek 35 százalékának (138 válaszadónak) volt korábbi önkéntes tapasztalata (2. ábra). Ez a mintabeli arány közel azonos, mint a teljes népességben, a 18-29 éves korosztályban mért szervezeti önkéntesek aránya (Gyorgyovich et al. 2020).

2. ábra Már a pandémia elött is önkéntes tevékenységet végzők aránya szakonként és évfolyamcsoportonként

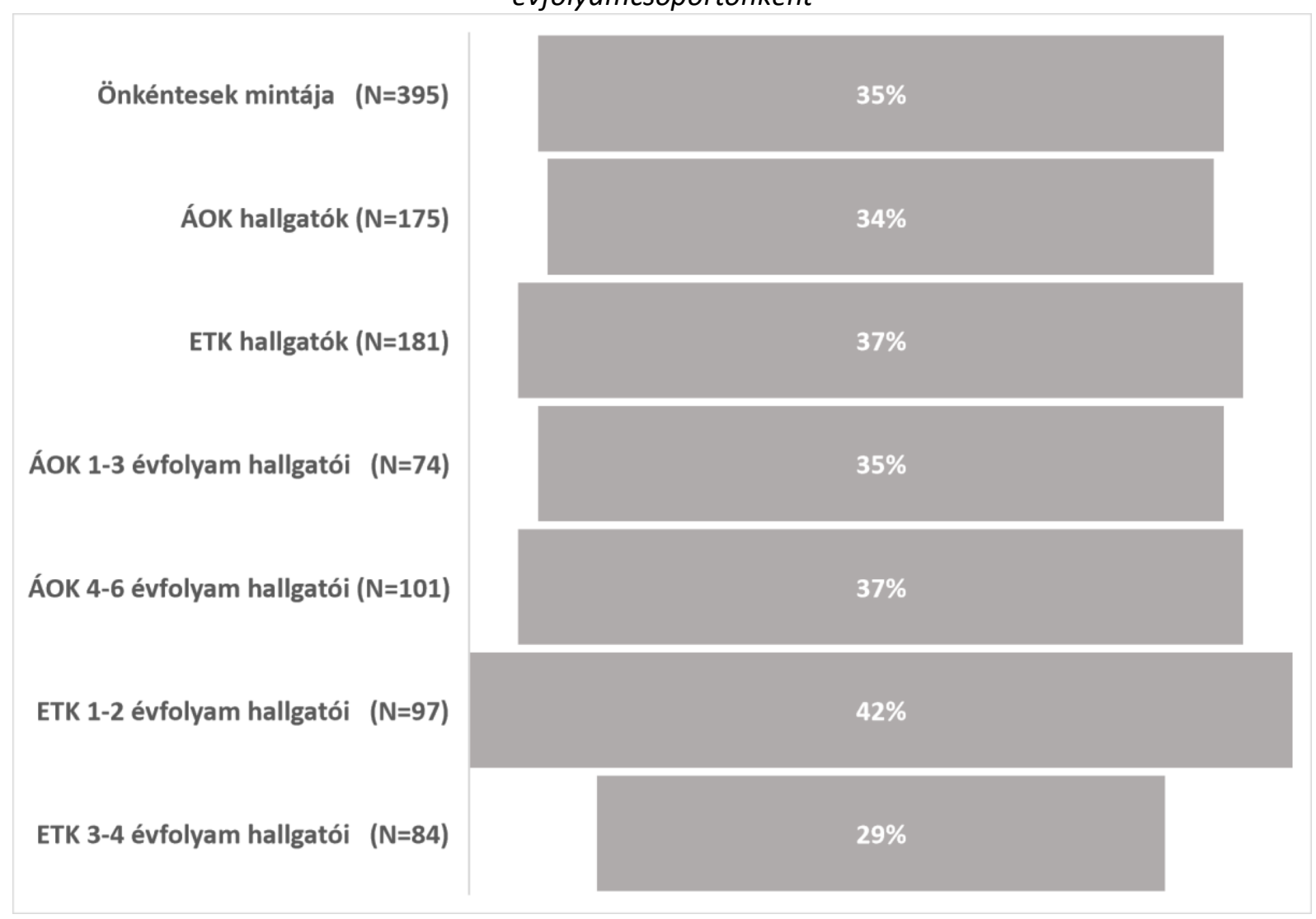

Forrás: saját szerkesztésű ábra adatbázis alapján

A szakok és évfolyamcsoportok szerint elemzés azt mutatta, hogy míg az általános orvos hallgatók között a korábbi önkéntes tapasztalatokkal rendelkezők aránya a minta átlaga körüli volt, addig az egészségtudományi szakos alsóbb évfolyamos válaszadók között voltak a legnagyobb arányban (42 százalék) azok, akik a pandémiát megelőzően is voltak önkéntesek. Ugyanakkor az egészségtudományi szakos felsőbb évfolyamos hallgatók körében a legalacsonyabb volt a korábbi önkéntes tapasztalatokkal rendelkezők aránya. 
A pandémia előtti önkéntesség rendszerességét vizsgálva azt találtuk, hogy az általános orvos hallgatók között, ha gyengén is, de szignifikánsan ${ }^{25}$ magasabb volt a régebb óta (24 hónapja vagy annál több) önkéntesek aránya, ez azonban inkább alkalmi és epizodikus önkéntesség volt. Az egészségtudományi hallgatók között pedig szignifikánsan magasabb volt a "friss” (24 hónapnál nem régebbi), de rendszeres önkéntesek aránya. Évfolyamonként is különbségeket találtunk a korábbi önkéntesség rendszeressége között: a preklinikai évfolyamok hallgatói inkább alkalmi, a klinikai évfolyamok hallgatói pedig inkább rendszeres önkéntesek voltak a pandémia előtt. Ez az egészségtudományi hallgatók esetében éppen ellentétesen alakult: a rendszeres önkéntesek inkább az alacsonyabb évfolyamokból kerültek ki, míg az alkalmi, epizodikus önkéntesek a magasabb évfolyamok hallgatói közül.

\section{A PANDÉMIA ALATTI ÖNKÉNTESEK NÉGY ALCSOPORTJÁNAK JELLEMZŐI ÉS MOTIVÁCIÓ।}

A pandémia alatti önkéntesek mintáját - a korábbi önkéntes tapasztalatok alapján és a pandémia alatti önkéntesség gyakorisága szerint - négy alcsoportra osztottuk.

\section{Elkötelezettek alcsoportja}

Az első alcsoportba azok az önkéntesek tartoztak (a minta 22 százaléka, 86 fő), akiknek voltak korábbi önkéntes tapasztalataik és a pandémia alatt is több alkalommal végeztek önkéntes munkát. Döntő többségük (87 százalékuk) rendszeresen (havonta 2-4 alkalommal) és elsősorban az OMSZ-nél, másodsorban kórházakban teljesített szolgálatot. Az alcsoportot főként a klinikai évfolyamok hallgatói, valamint első-másodéves egészségtudományi hallgatók alkották. Több mint háromötödük két egyetem - a Semmelweis és a Debreceni Egyetem hallgatóihoz tartozott. Az önkéntesség nagyobb részük számára megbecsülést és elismerést, míg kisebbik részüknek tapasztalatszerzést jelentett. A pandémia alatti önkéntességük negatív tapasztalatai valamivel kevesebb, mint kétötödüknek a problémás beteg vagy munkatársi kapcsolatokban, és a (külső és belső) stresszben mutatkozott meg (5. táblázat). Felszíni motivációikat ${ }^{26}$ a magas átlagértékek jellemezték, és elsősorban az érték $(M=4,15)$, megértés

\footnotetext{
$25 \mathrm{p}=0,004 ;$ Cramer's $=0,254$

${ }^{26}$ A motivációs faktorok átlagpontjai az önkéntesek felszíni motivációit mutatják meg, amelyek az önkéntes magatartás fenntartását segítik. Az egyes motivációs faktorok item-jeire adott átlagpontok pedig azokat a háttérmotivációkat tárják fel, amelyek az önkéntesmotivációk mögöttes folyamatainak dinamikáját jelzik.
} 
$(M=4,11)$, önbecsülés $(M=3,85)$ és az elismerés $(M=3,83)$ motivációk alkották. $A$ háttérmotivációik szélesek voltak, ugyancsak magas átlagértékekkel, amiből egy társadalmi ügyekre érzékeny, altruista, gyakorlati tapasztalatok elsajátításában motivált alcsoport képe rajzolódik ki. Önkéntességüket föként az önkéntesség öröme $(M=4,44)$, egy társadalmi csoport melletti elköteleződés $(M=4,32)$, a gyakorlati tapasztalatok $(M=4,28)$, egy társadalmi ügy fontossága $(M=4,24)$, jelen esetben a járvány elleni küzdelem, valamint az altruista segítés $(M=4,22)$ határozták meg (6. táblázat). A magas arányú rendszeres és a pandémia alatt többszöri önkéntességük, valamint a többségükre jellemző „érdeknélküli” önkénteselköteleződés, továbbá széles felszíni és háttérmotivációik miatt ezt a alcsoportot az „elkötelezettek" alcsoportjának neveztük el.

\section{Csalódottak alcsoportja}

A második alcsoportba olyan válaszadók kerültek be (a minta 13 százaléka, 52 fő), akik korábban már voltak önkéntesek, de a pandémia alatt csak egy időszakban vállaltak önkéntességet. Az alcsoportba tartozók leginkább az első évfolyamok hallgatói közül kerültek ki - mind az orvostanhallgatók, mind az egészségtudományi szakosok esetében - és közel felük (48 százalékuk) a Semmelweis Egyetem hallgatója volt. Önkéntes-elköteleződésük a minta átlagát hozta (4. táblázat), de több mint egyötödük (23 százalékuk) nem vállalta volna az önkéntességet juttatások nélkül. Magas volt körükben azoknak az aránya (57 százalék), akiknek egzisztenciális helyzete is befolyásolta a pandémia alatti önkéntesség vállalását. Kétharmaduk önkéntessége rendszeres volt (havonta 2-4 alkalommal), és ezt leginkább az OMSZ-nél teljesítették (5. táblázat). A pandémia alatti önkéntesség egyharmaduknak szakmai tapasztalatot, míg valamivel kevesebb, mint kétötödüknek elismerést jelentett. $A z$ önkéntességgel kapcsolatos negatív tapasztalatok említése körükben volt a legmagasabb: 40 százalékuk a problémás munkatársi kapcsolatokat, míg 30 százalékuk a hiányos felkészítést említette leginkább. Döntően két felszíni motiváció határozta meg önkéntességüket, az értékek $(M=3,77)$ és a megértés $(M=3,64)$, és három magasabb értékű háttérmotivációjuk volt: az altruista segítés $(M=4,02)$, az önkéntesség öröme $(M=3,98)$, és az új lehetőségek megtapasztalása $(M=3,86)$ a járványhelyzet által (6. táblázat). Az ebbe a csoportba tartozók, noha nem tapasztalatlanul léptek be a pandémia alatti önkéntességbe, de feltehetően hiányos felkészítésük, képzetlenségük (többségük az alsóbb évfolyamokból került ki) és 
motiválatlanságuk miatt valószínúleg számos negatív, frusztráló hatás érhette őket, ezért neveztük el ezt az alcsoportot a „csalódottak” alcsoportjának.

5. táblázat A pandémia alatt önkéntesek négy csoportja és jellemzőik

\begin{tabular}{|c|c|c|c|c|c|}
\hline & & $\begin{array}{c}\text { Elkötelezettek } \\
\text { (korábban volt } \\
\text { önkéntes és a } \\
\text { pandémia alatt } \\
\text { több } \\
\text { időszakban) } \\
\text { N=86 }\end{array}$ & $\begin{array}{c}\text { Csalódottak } \\
\text { (korábban } \\
\text { volt } \\
\text { önkéntes, de } \\
\text { a pandémia } \\
\text { alatt egy } \\
\text { időszakban) } \\
\mathrm{N}=52\end{array}$ & $\begin{array}{l}\text { Tapasztalat- } \\
\text { szerzők } \\
\text { (korábban } \\
\text { nem volt } \\
\text { önkéntes, de } \\
\text { a pandémia } \\
\text { alatt több } \\
\text { időszakban) } \\
\text { N=155 }\end{array}$ & $\begin{array}{c}\text { Akik } \\
\text { megpróbálták } \\
\text { (korábban nem } \\
\text { volt önkéntes, } \\
\text { és a pandémia } \\
\text { alatt egy } \\
\text { időszakban) } \\
\mathrm{N}=102\end{array}$ \\
\hline \multirow[t]{2}{*}{ ÁOK } & 1-3 évfolyam & $32 \%$ & $66 \%$ & $32 \%$ & $66 \%$ \\
\hline & 4-6 évfolyam & $68 \%$ & $34 \%$ & $68 \%$ & $34 \%$ \\
\hline \multirow[t]{2}{*}{ ETK } & 1-2 évfolyam & $58 \%$ & $68 \%$ & $47 \%$ & $51 \%$ \\
\hline & 3-4 évfolyam & $42 \%$ & $32 \%$ & $53 \%$ & $49 \%$ \\
\hline \multicolumn{2}{|c|}{ GYTK, FOK } & $5 \%$ & $8 \%$ & $8 \%$ & $15 \%$ \\
\hline \multirow[t]{4}{*}{ Egyetemek } & $\mathrm{DE}$ & $33 \%$ & $14 \%$ & $20 \%$ & $31 \%$ \\
\hline & PTE & $20 \%$ & $20 \%$ & $29 \%$ & $16 \%$ \\
\hline & SE & $34 \%$ & $48 \%$ & $29 \%$ & $31 \%$ \\
\hline & SZTE & $13 \%$ & $18 \%$ & $22 \%$ & $22 \%$ \\
\hline \multirow{3}{*}{$\begin{array}{l}\text { Juttatás nélkül is } \\
\text { vállalta volna az } \\
\text { önkéntességet }\end{array}$} & egyetért & $60 \%$ & $57 \%$ & $55 \%$ & $54 \%$ \\
\hline & bizonytalan & $31 \%$ & $20 \%$ & $25 \%$ & $21 \%$ \\
\hline & nem ért egyet & $9 \%$ & $23 \%$ & $20 \%$ & $25 \%$ \\
\hline \multirow{3}{*}{$\begin{array}{l}\text { Szüksége volt az } \\
\text { önkéntességért } \\
\text { kapott pénzre }\end{array}$} & egyetért & $54 \%$ & $57 \%$ & $51 \%$ & $54 \%$ \\
\hline & bizonytalan & $30 \%$ & $14 \%$ & $21 \%$ & $21 \%$ \\
\hline & nem ért egyet & $16 \%$ & $29 \%$ & $28 \%$ & $25 \%$ \\
\hline \multirow{3}{*}{$\begin{array}{l}\text { Az önkéntesség } \\
\text { rendszeressége }\end{array}$} & rendszeres & $87 \%$ & $67 \%$ & $78 \%$ & $66 \%$ \\
\hline & alkalmi & $5 \%$ & $15 \%$ & $9 \%$ & $9 \%$ \\
\hline & epizodikus & $8 \%$ & $18 \%$ & $13 \%$ & $25 \%$ \\
\hline \multirow{4}{*}{$\begin{array}{c}\text { Az önkéntesség } \\
\text { helye }\end{array}$} & kórház, klinika & $38 \%$ & $36 \%$ & $51 \%$ & $35 \%$ \\
\hline & OMSZ & $47 \%$ & $50 \%$ & $37 \%$ & $55 \%$ \\
\hline & OMSZ, kórház & $13 \%$ & $2 \%$ & $10 \%$ & $5 \%$ \\
\hline & civil szervezet & $2 \%$ & $12 \%$ & $2 \%$ & $5 \%$ \\
\hline \multirow{4}{*}{$\begin{array}{c}\text { Pozitív } \\
\text { tapasztalatok }\end{array}$} & megbecsülés & $50 \%$ & $42 \%$ & $46 \%$ & $39 \%$ \\
\hline & $\begin{array}{c}\text { tapasztalat- } \\
\text { szerzés }\end{array}$ & $23 \%$ & $30 \%$ & $39 \%$ & $25 \%$ \\
\hline & közösség & $5 \%$ & $10 \%$ & $2 \%$ & $25 \%$ \\
\hline & egyéb & $12 \%$ & $18 \%$ & $13 \%$ & $11 \%$ \\
\hline \multirow{4}{*}{$\begin{array}{c}\text { Negatív } \\
\text { tapasztalatok }\end{array}$} & szervezetlenség & $19 \%$ & $15 \%$ & $37 \%$ & $33 \%$ \\
\hline & felkészítés & $10 \%$ & $30 \%$ & $19 \%$ & $27 \%$ \\
\hline & $\begin{array}{c}\text { negatív } \\
\text { kapcsolatok }\end{array}$ & $39 \%$ & $40 \%$ & $22 \%$ & $20 \%$ \\
\hline & stressz & $32 \%$ & $15 \%$ & $22 \%$ & $20 \%$ \\
\hline
\end{tabular}

Forrás: saját szerkesztésű táblázat adatbázis alapján 


\section{Tapasztalatszerzők alcsoportja}

A harmadik alcsoportba - amelyet olyan válaszadók alkottak, akiknek nem volt korábbi önkéntes tapasztalatuk, de a pandémia alatt több időszakban is voltak önkéntesek - tartozott a minta 39 százaléka (155 fő). Ennek az alcsoportnak túlnyomó részét felsőbbéves hallgatók alkották, mind az orvosi, mind pedig az egészségtudományi szakokról. Több mint felük (58 százalékuk) a Semmelweis és a PTE hallgatói közül került ki (5. táblázat). Önkénteselköteleződésük a minta átlagánál valamivel alacsonyabb volt (4. táblázat), de közel egyharmaduk (28 százalék) úgy nyilatkozott, hogy nem volt szükségük az önkéntességért kapott pénzre. Több, mint háromnegyedük önkéntessége rendszeres volt (havonta 2-4 alkalommal) és 51 százalékuk kórházban vagy klinikán, míg 47 százalékuk pedig az OMSZ-nél és plusz még kórházakban is volt önkéntes.

A pandémia alatti önkéntesség többségüknek az elismerést jelentette, de körükben volt a legmagasabb azok aránya, akik a tapasztalatszerzést is megemlítették, az önkéntesség pozitív hozadékát. A „legérzékenyebbek” voltak az önkéntességet kísérő szervezetlenségre, mint negatív tapasztalatra. Felszíni motivációikat - szinte azonos átlagértékekkel - az értékek $(M=3,88)$ és a megértés $(M=3,82)$ motivációs faktorok alkották, amit az elismerés $(M=3,61)$ követett (6. táblázat). Háttérmotivációik hasonlóan szélesek voltak, mint az elkötelezettek csoportjának, de alacsonyabb átlagértékkel: a társadalmi csoport melletti elköteleződés $(M=4,09)$ után az altruizmus-segítés $(M=4,06)$, majd pedig a társadalmi ügy - a járványhelyzet melletti - melletti kiállás $(M=4,05)$ és a gyakorlati tapasztalatok $(M=4,00)$ következett. Meg kell jegyezni, hogy ebben a csoportban volt a legalacsonyabb az „önkéntesség öröme” item átlaga $(M=3,84)$. Pandémia alatti önkéntességükben a tapasztalatszerzés kiemelkedő fontossága azt mutatja, hogy szolgálatuk sokkal inkább a szakmai hátterhez kapcsolódott, mint az önkéntes munka eredendő vágyához. Ezért ezt a csoportot a „tapasztalatszerzők” csoportjának neveztük el.

\section{Akik megpróbálták alcsoportja}

Végezetül a negyedik alcsoportba azok a válaszadók (a minta 26 százaléka, 102 fő) tartoztak, akiknek nem volt korábbi önkéntes tapasztalatuk és csak egy időszakban voltak önkéntesek a pandémia alatt. Ennek az alcsoportnak az egyik jellemzője volt - hasonlóan a csalódottak alcsoportjához -, hogy mindkét szakról az alsóbb évfolyamok hallgatói, valamint a fogorvosok, gyógyszerészek többsége tartozott ide. Hatvankét százalékuk két egyetem, a Semmelweis és 
6. táblázat A pandémia alatti önkéntesek négy csoportjának felszíni és háttérmotivációi

\begin{tabular}{|c|c|c|c|c|c|c|c|c|}
\hline & \multicolumn{2}{|c|}{$\begin{array}{l}\text { Elkötelezettek } \\
\qquad \mathrm{N}=86\end{array}$} & \multicolumn{2}{|c|}{$\begin{array}{l}\text { Csalódottak } \\
\quad \mathrm{N}=52\end{array}$} & \multicolumn{2}{|c|}{$\begin{array}{c}\text { Tapasztalat- } \\
\text { szerzők } \\
\text { N=155 }\end{array}$} & \multicolumn{2}{|c|}{$\begin{array}{c}\text { Akik } \\
\text { megpróbálták } \\
\mathrm{N}=102\end{array}$} \\
\hline & M & SD & $\mathrm{M}$ & SD & $\mathrm{M}$ & SD & $\mathrm{M}$ & SD \\
\hline Érték1_társadalmi csoport & 4,32 & 0,930 & 3,82 & 1,178 & 4,09 & 1,051 & 4,07 & 1,033 \\
\hline Érték2_altruizmus_sajnálat* & 3,98 & 1,080 & 3,55 & 1,331 & 3,54 & 1,088 & 3,70 & 1,106 \\
\hline Érték3_altruizmus_empátia* & 4,00 & 0,976 & 3,62 & 1,276 & 3,56 & 1,056 & 3,64 & 1,169 \\
\hline Érték4_altruizmus_segítés & 4,22 & 1,100 & 4,02 & 1,911 & 4,06 & 1,058 & 4,17 & 1,021 \\
\hline Érték5_társadalmi ügy & 4,24 & 1,017 & 3,80 & 1,442 & 4,05 & 1,095 & 4,11 & 1,169 \\
\hline Értékek & 4,15 & 0,85 & 3,77 & 1,13 & 3,88 & 0,91 & 3,91 & 0,95 \\
\hline Megértés1_perspektíva & 4,11 & 1,232 & 3,86 & 1,342 & 3,89 & 1,251 & 3,96 & 1,181 \\
\hline $\begin{array}{l}\text { Megértés2_gyakorlati } \\
\text { tapasztalatok* }\end{array}$ & 4,28 & 1,134 & 3,61 & 1,358 & 4,00 & 1,270 & 3.87 & 1,359 \\
\hline Megértés3_emberek* & 4,13 & 1,044 & 3,50 & 1,389 & 3,81 & 1,233 & 3,61 & 1,238 \\
\hline Megértés4_erősségek & 3,98 & 1,023 & 3,46 & 1,313 & 3,62 & 1,198 & 3,68 & 1,292 \\
\hline Megértés* & 4,11 & 0,90 & 3,64 & 1,15 & 3,82 & 1,04 & 3,73 & 1,06 \\
\hline $\begin{array}{c}\text { Karrierfejlesztés1_kapcsolat } \\
\text { építés* }\end{array}$ & 3,98 & 1,151 & 3,27 & 1,469 & 3,64 & 1,399 & 3,62 & 1,373 \\
\hline Karrierfejlesztés2_nyitottság* & 3,05 & 1,413 & 2,45 & 1,443 & 2,64 & 1,39 & 2,29 & 1,385 \\
\hline Karrierfejlesztés3_skill* & 3,86 & 1,264 & 3,18 & 1,508 & 3,69 & 1,270 & 3,50 & 1,401 \\
\hline Karrierfejlesztés* & 3,61 & 1,00 & 2,98 & 1,21 & 3,32 & 1,10 & 3,12 & 1,04 \\
\hline Elismerés1_szervezeti* & 3,73 & 1,134 & 3,12 & 1,33 & 3,36 & 1,242 & 3,34 & 1,336 \\
\hline Elismerés2_mtarsak* & 4,16 & 0,992 & 3,47 & 1,172 & 3,9 & 1,115 & 4,14 & 0,957 \\
\hline Elismerés3_visszajelzés* & 3,45 & 1,258 & 2,80 & 1,258 & 3,5 & 1,155 & 3,34 & 1,186 \\
\hline Elismerés4_egyenlő & 4,06 & 1,203 & 3,55 & 1,370 & 3,87 & 1,181 & 3,85 & 1,194 \\
\hline Elismerés 5_társadalmi* & 3,65 & 1,202 & 3,00 & 1,443 & 3,34 & 1,296 & 3,45 & 1,219 \\
\hline Elismerés* & 3,83 & 0,73 & 3,18 & 0,80 & 3,61 & 0,78 & 3,62 & 0,76 \\
\hline Reciprocitás1_kapás & 3,70 & 1,243 & 3,58 & 1,458 & 3,35 & 1,359 & 3,39 & 1,329 \\
\hline Reciprocitás2_adás & 3,76 & 1,209 & 3,52 & 1,418 & 3,36 & 1,308 & 3,52 & 1,243 \\
\hline Reciprocitás & 3,73 & 1,19 & 3,54 & 1,40 & 3,35 & 1,29 & 3,44 & 1,22 \\
\hline Önbecsülés1_öröm* & 4,44 & 0,869 & 3,98 & 1,237 & 3,84 & 1,216 & 3,93 & 1,160 \\
\hline Önbecsülés2_jóember & 3,71 & 1,281 & 3,70 & 1,313 & 3,54 & 1,139 & 3,76 & 1,318 \\
\hline Önbecsülés3_fontosság & 3,49 & 1,346 & 3,22 & 1,404 & 3,10 & 1,380 & 3,26 & 1,242 \\
\hline Önbecsülés4_hasznosság* & 4,19 & 1,058 & 3,60 & 1,31 & 3,79 & 1,257 & 3,88 & 1,252 \\
\hline Önbecsülés5_elfoglatság* & 3,17 & 1,463 & 2,81 & 1,621 & 2,82 & 1,444 & 2,45 & 1,329 \\
\hline Önbecsülés* & 3,85 & 0,90 & 3,46 & 1,08 & 3,42 & 1,03 & 3,45 & 0,91 \\
\hline Kormányzat1_támogatáshiány & 3,25 & 1,482 & 3,06 & 1,557 & 2,8 & 1,464 & 2,77 & 1,425 \\
\hline Kormányzat2_forráshiány & 3,2 & 1,538 & 2,94 & 1,621 & 2,84 & 1,452 & 2,82 & 1,533 \\
\hline Kormányzat3_öntevékenység* & 3,89 & 1,161 & 3,63 & 1,395 & 3,3 & 1,355 & 3,42 & 1,32 \\
\hline Kormányzati hiányok* & 3,46 & 1,15 & 3,23 & 1,29 & 2,98 & 1,14 & 3,03 & 1,18 \\
\hline
\end{tabular}

Forrás: saját szerkesztésű táblázat adatbázis alapján

*A jelölt motivációs faktorok és itemek tekintetében szignifikáns különbség volt $(p \leq 0,05)$ az önkéntesek csoportjai között az ANOVA teszt szerint

Debreceni Egyetem hallgatói közül kerültek ki. A vizsgálati minta átlagánál (4. táblázat) alacsonyabb volt körükben az önkéntes-elköteleződés és a négy alcsoport közül itt volt a legmagasabb azok aránya (25 százalék), akik juttatások nélkül nem vállalták volna az önkéntességet. Kétharmaduk rendszeresen (havonta 2-4 alkalommal) önkénteskedett, míg 
több mint negyedük epizodikusan, és ezt az OMSZ-nél, illetve kórházakban végezték. Az önkéntesség közel kétötödük számára megbecsülést, egynegyedüknek tapasztalatszerzést, és másik egynegyedüknek közösséghez, csapathoz tartozást is jelentett, ami más csoportokban ennyire direkten nem jelent meg.

Az önkéntesség negatív élménye harmaduk számára a szervezetlenségből és több mint egynegyedük számára pedig a felkészítés hiányosságából fakadt. Felszíni motivációik sorrendje hasonló volt a tapasztalatszerzők alcsoportjáéhoz, csak valamivel magasabb átlagértékekkel az érték $(M=3,91)$ motivációs faktor esetében, de alacsonyabb a megértés $(M=3,73)$, és azonos átlagértékekkel az elismerés $(M=3,62)$ motivációs faktor tekintetében.

Háttérmotivációikat elsősorban az altruista segítés $(M=4,17)$, másodsorban csoportsajátosságként - a munkatársak elismerése $(M=4,14)$, harmadrészt egy társadalmi ügy $(M=4,11)$ és végül egy társadalmi csoport melletti elköteleződés $(M=4,07)$ alkotta (6. táblázat). A minta átlagánál alacsonyabb önkéntes-elköteleződés (4. táblázat), az epizodikus önkéntesek magas aránya miatt ezt az alcsoportot, „akik megpróbálták” alcsoportnak neveztük el.

Az önkéntesek négy alcsoportjának elemzése alapján igazolódott az a feltételezésünk, hogy hogy legerősebb felszíni motivációkat - hasonlóan Astorp et al. (2021) és Shi et al. (2021) eredményeihez - az altruista motivációk (érték motivációs faktor), a tanulási tapasztalatok (megértés motivációs faktor) és az elismerés (önbecsülés motivációs faktor) határozták meg, különböző erősséggel. További hipotézisünkkel egyezően a pandémia alatti önkéntesek alcsoportjaiba tartozók - különbség nélkül - erősen, társadalmi szociális értékek és a segítés által motivált önkéntesek voltak. Igaznak bizonyult az a feltevésünk is, hogy az „elkötelezettek” mutatkoztak a legmotiváltabbnak, és pandémia alatti önkéntességüket erős és széles - kevert típusú, altruista és individualista - háttérmotivációk határozták meg.

A pandémia alatti önkéntesek négy alcsoportjának motivációi közötti különbségeket vizsgálva azt találtuk, hogy a hét felszíni motiváció közül ötben (megértés, elismerés, önbecsülés, karrierfejlesztés, kormányzati hiányok) szignifikáns eltérés volt az alcsoportok között, míg az értékek és a reciprocitás motivációkban nem volt különbség. Továbbá, a 27 háttérmotiváció közül 15 esetében ugyancsak szignifikánsan különbözött a négy alcsoport. 


\section{ÖSSZEGZÉS}

Tanulmányunk egy különleges helyzetben, a COVID-19 járvány három hulláma alatt vizsgálta az orvos- és egészségtudományi szakos hallgatók önkéntességét. Ez egy speciális önkéntes tevékenységként valósult meg, amit a szakirodalom a krízis vagy katasztrófa önkéntesség kategóriájába sorol. Ezt támasztja alá egyrészt, hogy a vizsgált önkéntesek motivációs struktúrája - különösen a társadalmi és szociális érték motivációk dominanciája tekintetében - sok hasonlóságot mutatott a vörösiszap-katasztrófa önkénteseinek motivációival (BartalFerencz 2015). Másrészt, a társadalmi-szociális értékek által erősen meghatározott motivációkban jelentősen eltértek a magyar 18-25 éves önkéntesek (Bartal - Kmetty 2011), de más egyetemista csoportok motivációitól (Fényes 2015; 2021) is.

Az általunk vizsgált, pandémia alatt önkéntes tevekénységet végző hallgatók munkafeltételei (védőruha, védőfelszerelés) megfeleltek a járvány idején elvárható biztonsági feltételeknek. Önkéntesként ellátott feladataikra való felkészítésük jellege nagyban függött attól, hogy kórházban, klinikán vagy az OMSZ-nél teljesítettek szolgálatot. Eredményeink arra utalnak, hogy az önkéntesség számos olyan pozitív tapasztalatot és megerősítést is jelentett a COVID19 járvány önkénteseinek számára, amelyek erősíthetik a szakmai elhivatottságukat. Önkéntességük negatív tapasztalatai alapján úgy találtuk, hogy ezek - mint például a problémás beteg- és munkatársi kapcsolatok, a külső stressz és trauma - kezelésére a hallgatók nem voltak felkészítve nem csak a járványhelyzet közepén, hanem azt vélelmezzük, hogy a tanulmányaik során sem.

A pandémia alatti önkéntes-elköteleződés vizsgálata alapján azt állapítottuk meg, hogy a COVID-19 járvány alatt önkéntességet vállaló hallgatók több mint a fele rendelkezett egyfajta „érdeknélküli” önkéntes-elköteleződéssel. Hipotézisünkkel egyezően ez a klinikai évfolyamok hallgatóira mutatkozott inkább érvényesnek, és rájuk volt jellemző az is, hogy gyakrabban voltak önkéntesek a pandémia alatt, ugyanakkor az egészségtudományi hallgatók között magasabb volt a korábbi önkéntes tapasztalattal rendelkezők aránya.

Az önkéntes-elköteleződést befolyásoló anyagi ösztönzők többszempontú vizsgálata azonban már azt mutatta, hogy a válaszadók csak 20 százalékára volt jellemző az a fajta „érdeknélküli” önkéntes-elköteleződés, amit nem befolyásoltak az anyagi ösztönzők. Kisebb hányaduk, 13 százalékuk önkéntességét kifejezetten az anyagi ösztönzők mozgatták, vélhetően egzisztenciális helyzetük miatt. Többségük (67 százalékuk) önkéntes-elköteleződését viszont 
kevert típusúnak találtuk, mivel bizonytalanok voltak vagy „érdeknélküliségükben” vagy pedig az anyagi ösztönzők szükségességét illetően.

A pandémia alatt önkéntes orvos- és egészségtudományi szakos hallgatók mintája nem volt homogén. Egyfelől, nemcsak szakonként, hanem - a szakirodalmi eredményekkel (Astorp et al. 2021; Michno et al. 2021; Sra et al. 2021) egyezően - évfolyamcsoportonként is különbséget mutattak az önkéntességre való felkészítésük jellegében, önkénteselköteleződésükben és az önkéntesség pozitív és negatív tapasztalatainak megítélésében. Eredményeink összhangban állnak a válaszadók azon véleményével, hogy a nagyobb hatékonyság és a kevesebb szakmai, emberi frusztráció elkerülése érdekében szükséges lett volna az önkéntes tevékenység differenciálására évfolyamcsoportonként is.

Másfelöl a korábbi önkéntes tapasztalat tekintetében, részben pedig a pandémia alatti önkéntesség gyakorisága alapján sem. Ezen változók mentén az önkéntesek négy alcsoportját tudtuk megkülönböztetni: „elkötelezettek”, „csalódottak”, „tapasztalatszerzők” és „akik megpróbálták" alcsoportokat. Ez a négy alcsoport nemcsak a kontextuális változók tekintetében mutatkozott eltérőnek, hanem önkéntes-motivációiban is.

A pandémia alatt az önkéntesek közel kétötöde a tapasztalatszerzők alcsoportjába tartozott. Erre az alcsoportra találtuk jellemzőnek Rovers et al. (2016) alapján azt, hogy önkéntesmotivációik sokkal inkább szolgálatuk szakmai hátteréhez kapcsolódott, mint az önkéntes munka eredendő vágyához. Hiszen, egy olyan csoportként írhatók le, amely a pandémia alatt találkozott az önkéntességgel először. Önkéntes-elköteleződésük a minta átlagánál valamivel alacsonyabb volt, de erős individualista motivációik (önbecsülés, szakmai tapasztalatok szerzése) - amelyek inkább befolyásolták őket, mint a többi alcsoport tagjait - hatottak az önkéntesség többszöri vállalására.

Az önkéntesek mintájának másik nagyobb alcsoportját azok alkották, akik ugyancsak a járványhelyzetben, de csak egyszer próbálták ki magukat az önkéntességben. Többek között ezért is illettük ezt az alcsoportot, „akik megpróbálták” elnevezéssel. Ennek az alcsoportnak a tagjait a sajnálat és a segítés altruista motivációi mellett leginkább a szakmai környezet visszajelzésétől függő, önmegerősítés vágya motiválta. Ezt a magas elismerés motivációt, úgy tûnik, az önkéntesség pozitív tapasztalatai visszaigazolták. A kérdés az, hogy mindezek, a pandémia alatti önkéntességből nyert tapasztalatok mennyire konvertálódnak majd egy későbbi rendszeres önkéntességben. 
Shi et al. (2021) eredményeivel egyezően az „elkötelezettek” csoportjára találtuk jellemzőnek, hogy a járványhelyzet „stimulálólan” hatott a dominánsan altruista motivációjú hallgatókra, ami a vizsgált önkéntesek egy kisebb csoportjára, egyötödére volt jellemző. Ők azok, akik korábbi önkéntes tapasztalatokkal felvértezve voltak önkéntesek a járvány idején, és ők azok, akik a legelkötelezettebbnek mutatkoztak pandémia alatti önkéntességüket illetően is.

Végezetül a minta legkisebb hányadát azok az önkéntesek alkották, akikben a korábban is megtapasztalt önkéntesség öröme és az állampolgári aktivitás megvolt, de feltételezhetően a járványhelyzet munkakörülményei és negatív élményeik miatt önkéntességük inkább kedvezőtlen tapasztalatokat hozott számukra.

Reményeink szerint a COVID-19 járvány alatti önkéntesek e differenciált elemzése hozzájárulhat az orvos- és egészségtudományi hallgatók pandémia alatti önkéntességének árnyaltabb értékeléséhez és hasznosítható tapasztalatokat nyújt jövőbeni képzésük újragondolásához, valamint az egészségügyi önkéntes-fogadó szervezetek önkéntesgyakorlatának fejlesztéséhez.

\section{IRODALOM}

Ahmed, Naseem - Khan, Aneequa - Naveed - Hafiz Abdullah - Moizuddin, Syed Muhammad - Khan, Javeria (2020): Concerns of undergraduate medical students towards an outbraek of COVID-19. International Journal of Current Medical and Pharmaceutical Research, 6(3) pp. 5055-5062.

Adejimi, Adebola Afolake - Odugbemi, Babatunde Adeniran - Odukoya, Oluwakemi Ololade Okunade, Kehinde Sharafadeen - Taiwo, Aminah Oluwatamilore - Osibogun, Akin (2021): Vollunteering during the COVID-19 pandemic: attitudes and perceptions of clinical medical and dental students in Lagos, Nigeria. Nigerian Postgraduate Medical Journal, 28(1) pp. 1-13. DOI: 10.4103/npmj.npmj_379_20

Astorp, Mike Sæderup - Blichfeldt Sørensen, Gustav Valentin Blichfeldt - Rasmussen, Sten Emmersen, Jeppe - Wolfhagen Erbs, Alexander (2020): Support for mobilising medical students to join the COVID-19 pandemic emergency heathcare workforce: a cross sectional questionnaire survey. British Medical Journal Open 10: e039082. DOI: 10.1136/bmjopen-2020-039082

Bartal Anna Mária - Kmetty Zoltán (2011): A magyar önkéntesek motivációi. Civil Szemle, 8(4) pp. 730.

Bartal Anna Mária - Ferencz Zoltán (2015): A vörösiszap- katasztrófa társadalmi hatásai. Budapest: Argumentum kiadó.

DeWitt, Dawn E. (2020): Fighting COVID-19: Enabling Graduating Students to Start Internship Early at Their Own Medical School. Annals of Internal Medicine.

https://www.acpjournals.org/doi/10.7326/M20-1262 
Dorner László (2013): Az önkéntesség pszichológiai vonatkozásainak szakirodalmi áttekintése. Magyar Pszichológiai Szemle 68(2) pp. 329-355.

Drexler, Richard - Hambrecht, Jan M. - Oldhafer, Karl J. (2020): Involvement of Medical students during the Coronavirus Disease 2019 pandemic: A cross-sectional survey study. Cereus 12(8) e10147. DOI 10.7759/cureus.10147

Fényes Hajnalka (2015): Önkéntesség és új típusú önkéntesség a felsőoktatási hallgatók körében. Debrecen: Egyetemi Kiadó.

Fényes Hajnalka (2021): Az elmúlt 10 év kutatási eredményei a felsőoktatási hallgatók önkéntességéről. Önkéntes Szemle 1(1) pp. 56-68. DOI: 10.53585/OnkSzem.2021.1.56-68

Ferreira, Marisa - Proença, Teresa - Proença, João F. (2012): Motivation among hospital volunteers: an empirical analysis in Portugal. International Review on Public and Nonprofit Marketing. 9., pp. 137-152. Fletcher, Thomas D. - Major, Debra A. (2004): Medical students' motivations to volunteer: An examination of the nature of gender differences. Sex Roles, 51. pp. 109-114.

Glikman, Daniel (2020): Vounteer activity by medical students during the initial phases of Covid-19. Published online: British Medical Journal Opinion June 12. https://blogs.bmj.com/bmj/2020/06/12/volunteer-activity-by-medical-students-during-the-initialphases-of-covid-19/

Gyorgyovich, Miklós - Menich Dóra - Simon Nikolett - Kollár Dávid - Szadorai Dóra (2020): Önkéntesség Magyarországon 2018. Budapest: Századvég Kiadó.

Harvey, Anne (2020): Covid-19: medical students and FY1 doctors to be given early registration to help combat Covid-19. British Medical Journal, 368. DOI:10.1136/bmj.m1268

Herman, Benjamin - Rosychuk, Rhonda - Bailey, Tracy - Lake, Robert - Yonge, Olive -Marrie, Thomas (2007): Medical students and pandemic influenza. Emerging Infectious Disease 13(11) pp. 1781-1783. DOI:10.3201/eid1311.070279

Hustinx, Lesley (2001): Individualism, and new styles of youth volunteering. Voluntary Action, 3(2) pp. 57-76.

Hustinx, Lesley - Lammertyn, Frans (2003): Colective and reflexive styles of volunteering: a sociological modernization perspective. International Journal of Voluntary and Nonprofit Organizations 14(2) pp. 167-187.

Hustinx, Lesley - Haski-Leventhal, Debbie - Handy, Femida (2008): One of a kind? Comparing episodic and regular volunteers at the Philadelphia Ronald McDonald House. International Journal of Volunteer Administration, 25(3) pp. 50-66.

Hyde, Melissa - Dunn, Jeff - Bax, Caitlin - Chambers Suzanne (2016): Episodic volunteering and retention: An integrated theoretical approach. Nonprofit and Voluntary Sector Quarterly, 45(1) pp. 4563.

Long, Nathaniel_- Wolpaw, Daniel R. - Boothe, David - Caldwell, Cathrine - Dillon, Peter - Gottshall, Lauren - Koetter, Paige - Pooshpas Paradis - Wolpaw, Terry - Gonzalo, Jed D. (2020): Contributions of health professions students to health system needs during the COVID-19 pandemic: Potential strategies and process for U.S. Medical Schools. Academic Medicine, 95(11) pp. 1679-1686. DOI: 10.1097/ACM.0000000000003611

Michno, Dominika - Tan, Jaclyn - Adelekan, Adediran - Wollard, Alexander (2021): How can we help? Medical students' views on thier role in the COVID-19 pandemic. Journal of Public Health, pp. 1-11. DOI: $10.1093 /$ pubmed/fdaa271 
Miller, David Gibbes - Pierson Leah - Doernberg Samuel (2020) The role of medical students during the COVID-19 pandemic. Annuals of Internals Medicine, Published online April 7. DOI: 10.7326/M201281

Riva, Michele - Paladino, Maria E. - Belingheri, Michael (2020): The role of medical students during the COVID-19 pandemic. Annuals of Internals Medicine, Published online November 17. DOI: 10.7326/L20-1194

Rosychuk, Rhonda - Bailey, Tracy - Haines, Christina - Lake, Robert - Herman, Benjamin - Yonge, Olive - Marrie, Thomas (2008): Willingness to volunteer during an influenza pandemic: perspectives from students and staff at a large Canadian university. Influenza and Other Respiratory Viruses, 2(2) pp.7179.

Rovers, John - Japs, Kelsey - Troung, Erica - Shah, Yogesh (2016): Motivations, barriers and ethical understanding of healthcare student volunteers on a medical service trip: a mixed methods stuy. $B M C$ Medical Education, 16(94) pp. 2-12. DOI:10.1186/s12909-016-0618-0

Shi, Yu - Zhang, Shu-e, Fan, Lihua, Sun, Tao (2021): What motivates medical students to engage in volunteer behavior during the COVID-19 outbreak? A large cross-sectional survey. Frontiers in Psychology, 11. pp.1-10. DOI: 10.3389/fpsyg.2020.569765

Soled, Derek - Goel, Shivangi - Barry, Danika - Erfani, Parsa - Joseph, Nicolos - Kochis, Michael Uppal, Nishant - Velasquez, David - Vora, Kruti - Scott, Kristin Woody (2020): Lessons from a Covid19 Medical Student Response Team. Academic Medicine 95(9) pp. 1384-1387.

Sra, Manraj - Gupta, Amulya - Jaiswal, Abhisek - Yadav, Kapil - Goswami, Anil - Goswami, Kiran (2021): Willingness to volunteer for medical students during the COVID-19 pandemic: Assessment at tertiary care hospital in India. medRxiv 2021.01.22.21250302; DOI: 10.1101/2021.01.22.21250302

Starr, Isaac (1976): Influenza in 1918: recollections of the epidemic in Philadelphia. Annals of Internal Medicine, 85(4) pp. 516-518. DOI:10.7326/0003-4819-85-4-516

Waight, Gina - Berhane, Abeba - Orton, Lorenzo - Cinti, Sandro - Billi, John E. - Kim, Christopher S. (2011): The role of the medical students in influenza pandemic response. Journal Emerging Management 9(2) pp. 60-66. DOI:10.5055/jem.2011.0054

West, John B. (2005): The physiological challenges of the 1952 Copenhagen poliomyelitis epidemic and a renaissance in clinical respiratory physiology. Journal of Applied Physiology, 99(2) pp. 424-432.

Zweigenhaft, Richard - Amstrong, Jo - Quintis, Frances - Riddick, Annie (1996): The Motivations and effectiveness of hospital Volunteers. Journal of Social Psychology, 136(1) pp. 25-34. 